\title{
Copper(I) Oxalate Complexes: Synthesis, Structures and Surprises ${ }^{\dagger}$
}

A. Timothy Royappa*, ${ }^{*}$, Andrew D. Royappa ${ }^{1}$, Raphael F. Moral ${ }^{1}$, Arnold L. Rheingold ${ }^{2}$, Robert

J. Papoular ${ }^{3}$, Deke M. Blum ${ }^{1}$, Tien Q. Duong ${ }^{1}$, Jacob R. Stepherson ${ }^{1}$, Oliver D. Vu ${ }^{1}$, Banghao

Chen $^{4}$, Matthew R. Suchomel ${ }^{5}$, James A. Golen ${ }^{6}$, Gilles André ${ }^{3}$, Nikolaos Kourkoumelis ${ }^{7}$, Andrew D. Mercer' ${ }^{1}$ Allegra M. Pekarek' ${ }^{1}$ Dylan C. Kelly ${ }^{1}$

${ }^{\dagger}$ Dedicated to Prof. S. Peter Tanner, on the occasion of his $75^{\text {th }}$ birthday.

${ }^{1}$ Department of Chemistry, University of West Florida, 11000 University Parkway, Pensacola, FL 32514, United States

${ }^{2}$ Department of Chemistry, University of California San Diego, Urey Hall 5128, mail code 0358, 9500 Gilman Drive, La Jolla, CA 92093, United States

${ }^{3}$ IRAMIS, Léon Brillouin Laboratory, CEA-Saclay, F-91191 Gif-sur-Yvette, France

${ }^{4}$ Department of Chemistry \& Biochemistry, Florida State University, 102 Varsity Way, Tallahassee, FL 32306, United States

${ }^{5}$ Advanced Photon Source, Argonne National Laboratory, Argonne, Illinois 60439, United States 
${ }^{6}$ Department of Chemistry, University of Massachusetts Dartmouth, 285 Old Westport Road, North Dartmouth, MA 02747, United States

${ }^{7}$ Department of Medical Physics, Medical School, University of Ioannina, Ioannina 45110, Greece

* Corresponding author. E-mail address: royappa@uwf.edu (A. T. Royappa)

KEYWORDS: copper(I), oxalate complexes, coordination compounds, chemical vapor deposition

ABSTRACT: A series of dinuclear copper(I) oxalate complexes was synthesized by the direct acid-base reaction of $\mathrm{Cu}_{2} \mathrm{O}$ with oxalic acid in ethanol with a ligand, or in neat ligand. The complexes incorporated a variety of ligands $\mathrm{L}(\mathrm{L}=$ triphenylphosphine, $1,2-$ bis(diphenylphosphino)ethane, triphenylphosphite, diisopropyl sulfide, cyclooctadiene and cyclohexylisocyanide) and had the general formula $\mathrm{L}_{n} \mathrm{Cu}\left(\mu_{2}-\mathrm{C}_{2} \mathrm{O}_{4}\right) \mathrm{CuL}_{n}(n=1$ or 2$)$. The

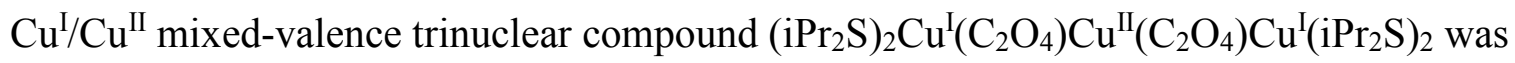
formed concomitantly with the target dinuclear $\mathrm{Cu}_{2} \mathrm{C}_{2} \mathrm{O}_{4}\left(\mathrm{iPr}_{2} \mathrm{~S}\right)_{4}$ complex, shedding light on the mechanism of disproportionation of this family of complexes. With norbornadiene (nbd) as a ligand, however, a coordination polymer $\mathrm{Cu}_{2} \mathrm{C}_{2} \mathrm{O}_{4}(\mathrm{nbd})$ was formed. Also, the same reaction with $\mathrm{L}=2,9$-dimethyl-1,10-phenanthroline or pyridine resulted in the known tetrahedral complex ions $[\mathrm{CuL} m]^{+}(m=2$ or 4$)$. Lastly, the ligand di-2-(1-di-(2-picolyl)amino)propyl 
disulfide produced not the expected $\mathrm{Cu}(\mathrm{I})$ oxalate complex, but a $\mathrm{Cu}(\mathrm{II})$ picolylamine oxalate coordination polymer. All products were structurally characterized by single-crystal X-ray diffraction if soluble, and by powder X-ray diffraction methods if not.

\section{INTRODUCTION}

Although copper(II) oxalate complexes are legion, the number of known copper(I) oxalate complexes is small, and of those, very few have been structurally characterized. Nevertheless, copper(I) oxalates have been studied for their key roles in a number of important applications, such as chemical vapor deposition of copper metal [1,2], atmospheric carbon dioxide fixation [3], carbon monoxide trapping [4], and deflagration of explosives [5].

Whereas copper(I) oxalate, $\mathrm{Cu}_{2} \mathrm{C}_{2} \mathrm{O}_{4}$, has long been known (as the dihydrate) [6], complexes of copper(I) oxalates with various ligands first made their appearance in the 1980s in the patent literature referenced above [4], in connection with industrial applications. However, as is frequently the case in these older papers and patents, the characterization data presented were very meager. Another early example of a copper(I) oxalate complex was a dinuclear triphenylphosphine complex reported by Gimeno et al. [7], structurally characterized later by the Lang group [8], which also reported a few other copper(I) oxalate phosphine complexes in the same paper. Lang et al. also reported a copper(I) oxalate complex with a bis(trimethylsilylpentadienyl)titanium bis(trimethylsilylacetylide) tweezer ligand, but the complex was not structurally characterized [9]. In a couple of seminal studies by Meyer, Köhler, and coworkers $[1,2]$, a series of copper(I) oxalate complexes with alkyne, alkene and isocyanide ligands were synthesized, a number of which were structurally characterized, not including alkene complexes. Our own group has recently published crystal structures of the copper(I) 
oxalate triphenylphosphine complex [10] mentioned above (with different solvation from that reported earlier) and of copper(I) tetrakisacetonitrile hydrogen oxalate [11].

The foregoing copper(I) oxalate complexes were synthesized by a variety of methods, e.g., acid-base reaction of oxalic acid with $\mathrm{Cu}_{2} \mathrm{O}$ in the presence of ligand; metathesis between a $\mathrm{Cu}(\mathrm{I})$ acetylacetonate complex and oxalic acid; ligand exchange with an alkyne or $\mathrm{CO}$ complex; reaction of a methylcopper(I) species with oxalic acid; electrochemical reaction of copper with oxalic acid; or metathesis between tetraalkylammonium oxalate and a tetrakisacetonitrile copper(I) salt in the presence of ligand. Among these various routes to copper(I) oxalate complexes, the most "synthetically unpretentious strategy" [12] is the first. The direct reaction of oxalic acid with $\mathrm{Cu}_{2} \mathrm{O}$ in the presence of ligand has a number of other advantages besides its simplicity: both oxalic acid and $\mathrm{Cu}_{2} \mathrm{O}$ are cheap and readily available; benign water is the only byproduct; $\mathrm{Cu}_{2} \mathrm{O}$ is purely basic [13], so side reactions from amphoteric behavior of the base are avoided; the disappearance of the vivid red solid $\mathrm{Cu}_{2} \mathrm{O}$ starting material is a built-in means of monitoring the reaction; and $\mathrm{Cu}_{2} \mathrm{O}$ is a strong enough base to react even with amine ligands that have formed solid salts with oxalic acid in the reaction mixture. However, other workers besides ourselves have noted that this reaction sometimes forms intractable mixtures of products: brownish solutions or brownish suspensions [14]. As well, previous implementations of this synthetic route involved solvents such as dichloromethane, pyridine, or THF, which are becoming less and less desirable, and some of which are difficult to remove during workup. Therefore, it seemed good to us also to investigate these complexes carefully again, with a particular emphasis on their synthesis by greener methods than before and on the structural characterization of the resulting complexes. In so doing, we have explored the scope of this simple reaction more fully and delineated major patterns of reactivity, in the process synthesizing 
and determining the structures of a number of new copper(I) oxalate complexes. Additionally, by the crystallization of a mixed-valence $\mathrm{Cu}^{\mathrm{I}} / \mathrm{Cu}^{\mathrm{II}}$ oxalate complex, we have gained insights into the mechanism of disproportionation of copper(I) oxalate complexes to copper(II) oxalate and copper metal. Lastly, we have uncovered a hitherto unknown reaction pathway involving copper(II) complexes of a much-studied $\mathrm{N}_{x} \mathrm{~S}_{y}$ ligand of current interest.

\section{EXPERIMENTAL METHODS}

General Synthetic Methods. All reactions were carried out under a nitrogen or argon atmosphere. Except where noted, starting materials and solvents were of reagent grade or better, obtained from commercial sources such as Acros or Sigma-Aldrich and used without further purification. The ligands 1,2-bis(diphenylphosphino)ethane [15] (dppe) and di-2-(1-di-(2picolyl)amino)propyl disulfide [3] (dppds) were synthesized by published methods. Solvents were degassed by purging with nitrogen through a septum for about $20 \mathrm{~min}$.

General Analytical Methods. Elemental analyses were carried out by ALS Global, Tucson, AZ, USA. FTIR spectra were obtained on a Perkin-Elmer Frontier spectrometer using an ATR attachment, as solids sandwiched between salt plates or as Nujol mulls. A total of eight scans were averaged, and spectra were collected at a resolution of $4 \mathrm{~cm}^{-1}$. Solution NMR spectra were measured on a Bruker Ascend 400 spectrometer, operating at $400.13 \mathrm{MHz}$ for ${ }^{1} \mathrm{H}$ and 161.98 MHz for ${ }^{31} \mathrm{P} .{ }^{1} \mathrm{H}$ spectra were referenced to TMS or the solvent residual peak, and ${ }^{31} \mathrm{P}$ spectra to $85 \% \mathrm{H}_{3} \mathrm{PO}_{4}(\mathrm{aq})$ contained in a sealed capillary in the NMR tube.

Solid-State NMR. All solid-state Magic Angle Spinning (MAS) NMR spectra were collected on a Bruker AVIII HD 500WB spectrometer equipped with three RF channels, operating at a field strength of $11.7 \mathrm{~T}$. The Larmor frequencies of ${ }^{1} \mathrm{H},{ }^{13} \mathrm{C}$ and ${ }^{31} \mathrm{P}$ were $500.34,150.82$, and 202.54 
MHz, respectively. For ${ }^{1}$ H CRAMPS (Combined Rotation And Multiple Pulse Spectroscopy) experiments, a DUMBOD2 pulse sequence was used for homonuclear decoupling; the $\pi / 2$ pulse width was $2.5 \mu$ s for a $100 \mathrm{kHz}$ RF field, and the recycle time was $10 \mathrm{~s}$. For the ${ }^{31} \mathrm{P}$ MAS experiment, a $30^{\circ}$ pulse was typically used, the recycle delay was $25 \mathrm{~s}$ and the spinning speed was $12 \mathrm{kHz}$. For the ${ }^{13} \mathrm{C}\left\{{ }^{1} \mathrm{H}\right\}$ Cross Polarization Magic Angle Spinning (CPMAS) experiments, the ${ }^{1} \mathrm{H} 90^{\circ}$ pulse length was $4 \mu \mathrm{s}$ and a repetition time of $10 \mathrm{~s}$ was used. The chemical shifts of ${ }^{1} \mathrm{H}$ and ${ }^{13} \mathrm{C}$ were referenced to TMS and that of ${ }^{31} \mathrm{P}$ to $85 \% \mathrm{H}_{3} \mathrm{PO}_{4}$. The MAS speed was $12 \mathrm{kHz}$ in all experiments.

Powder Diffraction Methods. Powder X-ray diffraction patterns for complex 2 were recorded using a Bruker-AXS D8-Advance diffractometer with a secondary beam graphite monochromator $\left(\mathrm{Cu}\right.$ source; $\left.\lambda=1.5418 \AA ; 2 \theta=3^{\circ}-101^{\circ}\right)$. High resolution powder X-ray diffraction data for complex 11 were recorded at beamline 11-BM of the Advanced Photon Source, Argonne National Laboratory. Data were measured at $295 \mathrm{~K}$ over the $2 \theta$ range of $1^{\circ}$ to $48^{\circ}$ using an incident wavelength of $0.41373 \AA$, with appropriate checks to ensure that there was no beam damage to the sample. Powder neutron diffraction data for $\mathbf{1 1}$ were recorded at the G41 powder diffraction beamline of the Orphée reactor at CEA-Saclay (neutron wavelength $\lambda=$ $2.42785 \AA$ ), calibrated using the reference compound $\mathrm{Na}_{2} \mathrm{Al}_{2} \mathrm{Ca}_{3} \mathrm{~F}_{14}$ [16]. Powder diffraction data obtained for $\mathbf{2}$ were pre-processed using the PowDLL software, numerically stripped of the Ka2 contribution using the maximum entropy method [17], and indexed with the EXPO2014 [18] and N-TREOR [19] software packages to obtain a unit cell. The FOX crystallographic software [20] was used to identify the space group and find the asymmetric unit by simulated annealing/parallel tempering [21]. Rietveld refinement was carried out using the GSAS program [22] using appropriate bond, angle, and planarity restraints, as well as some preferred orientation 
to give a chemically reasonable structural model with modest figures of merit, using data up to a resolution of $2 \AA\left(2 \theta=45^{\circ}\right)$. The unit cell of 11 was found by indexing the X-ray diffraction pattern using the DICVOL06 [23] and WinPloTR [24] packages, and structural refinement of the model was carried out as above using both neutron and X-ray data (“joint N-X refinement”).

Single Crystal X-ray Crystallography. Single-crystal diffraction data were collected on a Bruker Apex II CCD diffractometer at 100(2) K using Mo K $\alpha$ radiation $(\lambda=0.71073 \AA)$. After corrections were made for absorption and polarization effects, structure solution and refinement were carried out using the SHELX-97 software suite (or more recent versions) [25]. All nonhydrogen atoms were refined with anisotropic thermal displacement parameters, and hydrogen atoms were included at calculated positions. The software suite $O L E X 2$ was used for evaluation and graphical display of structures [26].

\section{Synthetic Details.}

Synthesis of $\mathrm{Cu}_{2}\left(\mathrm{C}_{2} \mathrm{O}_{4}\right)\left(\mathrm{PPh}_{3}\right)_{4}(\mathbf{1})$. A $10 \mathrm{~mL}$ round-bottom flask was charged with $1.049 \mathrm{~g}$ triphenylphosphine (4 mmol), $0.090 \mathrm{~g}$ anhydrous oxalic acid ( $1 \mathrm{mmol}), 0.145 \mathrm{~g} \mathrm{Cu}_{2} \mathrm{O}(1 \mathrm{mmol})$ and $5 \mathrm{~mL} \mathrm{95 \%} \mathrm{ethanol,} \mathrm{and} \mathrm{stirred} \mathrm{under} \mathrm{nitrogen.} \mathrm{The} \mathrm{entire} \mathrm{reaction} \mathrm{mixture} \mathrm{turned} \mathrm{milky}$ white in about $1 \mathrm{~h}$. Stirring continued for $16 \mathrm{~h}$, after which the reaction mixture was filtered on a Büchner funnel. The precipitate obtained was dried overnight in a fume hood to afford $\mathbf{1}$ as a white powder (1.205 g, 95\%), mp $\sim 235^{\circ} \mathrm{C}$ (dec.). Anal. Calcd for $\mathrm{C}_{74} \mathrm{H}_{60} \mathrm{Cu}_{2} \mathrm{O}_{4} \mathrm{P}_{4}: \mathrm{C}, 70.30 ; \mathrm{H}$, 4.78; $\mathrm{Cu}, 10.05 ; \mathrm{P}, 9.80$. Found: $\mathrm{C}, 70.33 ; \mathrm{H}, 5.21 ; \mathrm{Cu}, 10.17 ; \mathrm{P}, 8.41 \% .{ }^{1} \mathrm{H} \mathrm{NMR}\left(\mathrm{CD}_{2} \mathrm{Cl}_{2}\right): \delta$ 7.16 (br m, CH, 24H), 7.31 (br m, CH, 36H). ${ }^{31} \mathrm{P}$ NMR $\left(\mathrm{CD}_{2} \mathrm{Cl}_{2}\right): \delta-4.22\left(\mathrm{br}, P\left(\mathrm{C}_{6} \mathrm{H}_{5}\right)_{3}\right) . \mathrm{IR}\left(\mathrm{cm}^{-}\right.$ $\left.{ }^{1}\right): v_{\mathrm{C}=\mathrm{O}} 1614(\mathrm{~s})$. Crystals for single-crystal X-ray diffraction were grown by cooling a solution of ca. $15 \mathrm{mg} 1$ in ca. $2 \mathrm{~mL}$ hot $100 \%$ ethanol. 
Synthesis of $\mathrm{Cu}_{2}\left(\mathrm{C}_{2} \mathrm{O}_{4}\right)(\text { dppe })_{2}$ (2). In a $10 \mathrm{~mL}$ round-bottom flask, $0.097 \mathrm{~g}$ anhydrous oxalic acid (1 mmol) and $0.797 \mathrm{~g} \mathrm{1,2-bis(diphenylphosphino)ethane} \mathrm{(dppe,} 2 \mathrm{mmol}$ ) were dissolved in $6 \mathrm{~mL}$ $95 \%$ ethanol with stirring, followed by the addition of $0.145 \mathrm{~g} \mathrm{Cu}_{2} \mathrm{O}(1 \mathrm{mmol})$. Upon stirring for $2 \mathrm{~d}$ under nitrogen, the reaction mixture turned milky white. After filtration on a Büchner funnel, the precipitate collected was dried overnight in a fume hood to afford $\mathbf{2}$ as a white powder $(0.794$ g, 78\%), mp $\sim 230^{\circ} \mathrm{C}$ (dec.). Anal. Calcd for $\mathrm{C}_{54} \mathrm{H}_{48} \mathrm{Cu}_{2} \mathrm{O}_{4} \mathrm{P}_{4}: \mathrm{C}, 64.09 ; \mathrm{H}, 4.78 ; \mathrm{Cu}, 12.56 ; \mathrm{P}$, 12.24. Found: $\mathrm{C}, 62.04 ; \mathrm{H}, 4.98 ; \mathrm{Cu}, 12.61 ; \mathrm{P}, 12.35 \%$. This compound was insoluble in all common solvents, preventing solution NMR or single-crystal X-ray diffraction from being carried out. It was therefore analyzed by solid-state NMR and powder X-ray diffraction. ${ }^{1} \mathrm{H}$ NMR (solid-state, MAS-CRAMPS): $\delta 1.2\left(\mathrm{br}, \mathrm{CH}_{2}\right), 6.0$ (br, with sh at $\left.4.9 \mathrm{ppm}, \mathrm{CH}\right) .{ }^{13} \mathrm{C}\left\{{ }^{1} \mathrm{H}\right\}$ NMR (solid-state, CPMAS): $\delta 25\left(\mathrm{CH}_{2}\right), 132$ (br m, $\left.\mathrm{CH}\right), 171\left(\mathrm{C}_{2} \mathrm{O}_{4}\right) .{ }^{31} \mathrm{P}$ NMR (solid state, MAS): $\delta-14$ (br, $\left.P\left(\mathrm{C}_{6} \mathrm{H}_{5}\right)_{2}\right)$. IR $\left(\mathrm{cm}^{-1}\right): v_{\mathrm{C}=\mathrm{O}} 1616(\mathrm{~s})$.

Synthesis of $\mathrm{Cu}_{2}\left(\mathrm{C}_{2} \mathrm{O}_{4}\right)\left(\mathrm{P}(\mathrm{OPh})_{3}\right)_{4}(3)$. In a $25 \mathrm{~mL}$ round-bottom flask, $0.096 \mathrm{~g}$ anhydrous oxalic acid ( $1 \mathrm{mmol})$ and $1.265 \mathrm{~g}$ triphenylphosphite $(4 \mathrm{mmol})$ were dissolved in $10 \mathrm{~mL} 95 \%$ ethanol with stirring, after which $0.145 \mathrm{~g} \mathrm{Cu}_{2} \mathrm{O}(1 \mathrm{mmol})$ were added. The reaction mixture was stirred under nitrogen in an ice bath for $2 \mathrm{~d}$ until it turned milky white. The reaction mixture was filtered on a Büchner funnel through a $0.7 \mu \mathrm{m}$ glass fiber filter, and the resulting precipitate was dried overnight in a fume hood to afford 3 as a white powder faintly tinged with blue $(0.984 \mathrm{~g}, 68 \%)$, mp 105-110 ${ }^{\circ}$. Anal. Calcd for $\mathrm{C}_{74} \mathrm{H}_{60} \mathrm{Cu}_{2} \mathrm{O}_{16} \mathrm{P} 4: \mathrm{C}, 61.03 ; \mathrm{H}, 4.15 ; \mathrm{Cu}, 8.73 ; \mathrm{P}, 8.51$. Found: $\mathrm{C}$, 59.98; H, 4.92; $\mathrm{Cu}, 6.89 ; \mathrm{P}, 7.68 \% .{ }^{1} \mathrm{H}$ NMR $\left(\mathrm{CD}_{2} \mathrm{Cl}_{2}\right): \delta 7.11$ (br s, $\left.\mathrm{CH}, 36 \mathrm{H}\right), 7.30$ (br s, $\mathrm{CH}$, 24H). ${ }^{31} \mathrm{P}$ NMR $\left(\mathrm{CD}_{2} \mathrm{Cl}_{2}\right): \delta 112.43\left(\mathrm{br}, P\left(\mathrm{OC}_{6} \mathrm{H}_{5}\right)_{3}\right) . \mathrm{IR}\left(\mathrm{cm}^{-1}\right): v_{\mathrm{C}=\mathrm{O}} 1627$ (s); $v_{\mathrm{C}-\mathrm{O}-\mathrm{P}} 1186(\mathrm{~s})$, 1166 (s). Crystals for single-crystal X-ray diffraction were grown as follows: ca. $25 \mathrm{mg}$ of the product was dissolved in $1 \mathrm{~mL}$ boiling $100 \%$ ethanol, which was then filtered through a $0.2 \mu \mathrm{m}$ 
syringe filter into an NMR tube, layered with hexane and kept in a refrigerator at $5^{\circ} \mathrm{C}$ for a few days.

Synthesis of $\mathrm{Cu}_{2}\left(\mathrm{C}_{2} \mathrm{O}_{4}\right)\left(\mathrm{iPr}_{2} \mathrm{~S}\right)_{4} \cdot 4 \mathrm{H}_{2} \mathrm{O}$ (4). In a $10 \mathrm{~mL}$ oven-dried round-bottom flask, $0.098 \mathrm{~g}$ anhydrous oxalic acid $(1 \mathrm{mmol})$ was dissolved in $5 \mathrm{~mL}$ degassed diisopropyl sulfide $\left(\mathrm{iPr}_{2} \mathrm{~S}\right)$ with stirring, after which $0.144 \mathrm{~g} \mathrm{Cu}_{2} \mathrm{O}(1 \mathrm{mmol})$ was added. The resulting suspension was stirred under nitrogen for $2 \mathrm{~h}$ and filtered through a $0.45 \mu \mathrm{m}$ syringe filter. The clear green filtrate was placed in a $-27^{\circ} \mathrm{C}$ freezer overnight under nitrogen. The green supernatant was removed with a syringe and the remaining precipitate was allowed to dry under nitrogen flow to yield $\mathbf{4}$ as an airand temperature-sensitive white crystalline solid $(0.198 \mathrm{~g}, 26 \%)$. IR $\left(\mathrm{cm}^{-1}\right)$ : $v_{\mathrm{O}-\mathrm{H}} 3535(\mathrm{~m}), 3449$ $(\mathrm{m}) ; v_{\mathrm{C}=\mathrm{O}} 1637$ (s). This compound was too labile for a melting point to be obtained or elemental analysis to be performed. It also decomposed in solvents other than the ligand, preventing an NMR spectrum from being obtained. Crystals for single-crystal X-ray diffraction were grown by chilling the original green filtrate from the reaction mixture at $-27^{\circ} \mathrm{C}$ for two weeks instead of overnight. Colorless crystals of the target compound 4 were obtained, along with some green Xray quality crystals of a disproportionation byproduct (5).

Synthesis of $\mathrm{Cu}_{2}(\mathrm{tu})_{6} \mathrm{C}_{2} \mathrm{O}_{4} \cdot 2 \mathrm{H}_{2} \mathrm{O}$ (6). In a $25 \mathrm{~mL}$ Erlenmeyer flask, $305 \mathrm{mg}$ thiourea (tu, $4 \mathrm{mmol}$ ) and $126 \mathrm{mg}$ oxalic acid dihydrate $(1 \mathrm{mmol})$ were dissolved in $10 \mathrm{~mL} 95 \%$ ethanol at reflux in air, with stirring. This was followed by the addition of $0.142 \mathrm{~g} \mathrm{Cu}_{2} \mathrm{O}(1 \mathrm{mmol})$, most of which dissolved in about $2 \mathrm{~min}$. The reaction mixture was immediately filtered hot through a $0.2 \mu \mathrm{m}$ syringe filter, and the clear, colorless filtrate was left to sit in a corked flask for $19 \mathrm{~d}$ to yield small, colorless crystals. These were filtered and washed with $2 \times 1 \mathrm{~mL} \mathrm{95 \%} \mathrm{ethanol} \mathrm{to} \mathrm{yield} 6$ as a white powder $(0.040 \mathrm{~g}, 5 \%), \mathrm{mp} \sim 134^{\circ} \mathrm{C}$ (dec.), containing crystals suitable for single-crystal 
X-ray diffraction. Anal. Calcd for $\mathrm{C}_{8} \mathrm{H}_{28} \mathrm{Cu}_{2} \mathrm{~N}_{12} \mathrm{O}_{6} \mathrm{~S}_{6}: \mathrm{C}, 13.57 ; \mathrm{H}, 3.99 ; \mathrm{Cu}, 17.95 ; \mathrm{N}, 23.74 ; \mathrm{S}$, 27.18. Found: $\mathrm{C}, 14.21 ; \mathrm{H}, 4.49 ; \mathrm{Cu}, 17.34 ; \mathrm{N}, 23.25 ; \mathrm{S}, 27.15 \%$. This compound was practically insoluble in all common NMR solvents, precluding solution NMR analysis; it was therefore analyzed by solid-state NMR. ${ }^{1} \mathrm{H}$ NMR (solid-state, MAS-CRAMPS): $\delta 0.3\left(\mathrm{br}, \mathrm{OH} \mathrm{H}_{2}\right), 6.3(\mathrm{br}$, $\left.\mathrm{N} H_{2}\right) \cdot{ }^{13} \mathrm{C}\left\{{ }^{1} \mathrm{H}\right\}$ NMR (solid-state, CPMAS): $\delta 165$ (br m, CS $), 181\left(C_{2} \mathrm{O}_{4}\right) . \mathrm{IR}\left(\mathrm{cm}^{-1}\right): v_{\mathrm{N}-\mathrm{H}}$ and $v_{\mathrm{O}-\mathrm{H}} 3409(\mathrm{~m}), 3366(\mathrm{~m}), 3283(\mathrm{~m}), 3171(\mathrm{~m}) ; v_{\mathrm{C}=\mathrm{O}} 1611(\mathrm{~s}) ; v_{\mathrm{C}=\mathrm{S}} 1396(\mathrm{~m})$.

Synthesis of $\mathrm{Cu}\left(\right.$ dmphen ${ }_{2} \mathrm{HC}_{2} \mathrm{O}_{4}$ (7). A $10 \mathrm{~mL}$ round-bottom flask was charged with $0.144 \mathrm{~g}$ $\mathrm{Cu}_{2} \mathrm{O}$ (1 mmol), $0.434 \mathrm{mg}$ 2,9-dimethyl-1,10-phenanthroline (dmphen, $2 \mathrm{mmol}$ ), $0.090 \mathrm{~g}$ anhydrous oxalic acid ( $1 \mathrm{mmol}$ ), and $5 \mathrm{~mL} \mathrm{95 \%} \mathrm{ethanol.} \mathrm{After} \mathrm{stirring} \mathrm{for} 30 \mathrm{~min}$ under nitrogen, the dark red reaction mixture was evaporated under vacuum, and the resulting dark red solid washed with $3 \times 2 \mathrm{~mL}$ degassed THF (degassed 95\% ethanol may be substituted) under nitrogen using a cannula. The solid was sonicated for the first wash and stirred thoroughly on a vortex mixer during each wash. Drying the washed solid under a flow of nitrogen or under vacuum yielded 7 as a dark orange powder $(0.236 \mathrm{~g}, 21 \%), \mathrm{mp} \sim 225^{\circ} \mathrm{C}$ (dec.). Anal. Calcd for $\mathrm{C}_{30} \mathrm{H}_{25} \mathrm{CuN}_{4} \mathrm{O}_{4}: \mathrm{C}, 63.32 ; \mathrm{H}, 4.43 ; \mathrm{Cu}, 11.17 ; \mathrm{N}, 9.84$. Found: $\mathrm{C}, 59.71 ; \mathrm{H}, 5.03 ; \mathrm{Cu}, 14.57 ; \mathrm{N}$, 9.72\%. ${ }^{1} \mathrm{H}$ NMR ( $\mathrm{CD}_{3} \mathrm{OD}$ ): $\delta 2.48$ (br s, $\mathrm{CH}_{3}, 12 \mathrm{H}$ ), 7.90 (br d, $\mathrm{CH}, 4 \mathrm{H}, J=6.0 \mathrm{~Hz}$ ), 8.16 (br s,

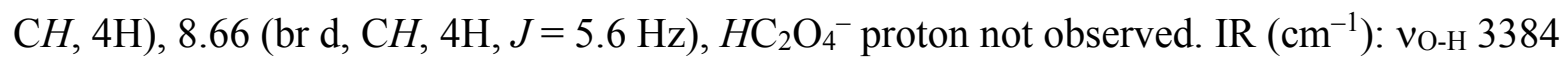
$(\mathrm{w}) ; v_{\mathrm{C}=\mathrm{O}} 1668$ (s). Crystals suitable for single-crystal X-ray diffraction were grown at room temperature by vapor diffusion of diethyl ether for $5 \mathrm{~d}$ into a solution containing $22 \mathrm{mg}$ of product dissolved in $0.75 \mathrm{~mL}$ degassed $100 \%$ ethanol.

Synthesis of $\mathrm{Cu}(\mathrm{py}){ }_{4} \mathrm{HC}_{2} \mathrm{O}_{4}(\mathbf{8})$. In an oven-dried $10 \mathrm{~mL}$ round-bottom flask, $0.091 \mathrm{~g}$ anhydrous oxalic acid ( $1 \mathrm{mmol}$ ) was dissolved in $5 \mathrm{~mL}$ degassed pyridine (py) with stirring. The flask was 
cooled to $-15^{\circ} \mathrm{C}$ in an ice-ethanol bath, $0.144 \mathrm{~g} \mathrm{Cu}_{2} \mathrm{O}(1 \mathrm{mmol})$ was added, and the mixture was stirred under nitrogen for $1 \mathrm{~h}$. After allowing the suspension to settle, the reaction mixture was filtered under nitrogen through a cannula into an empty RBF kept cold in an ice-ethanol bath. The light green supernatant was placed in a $-27^{\circ} \mathrm{C}$ freezer, and a large bed of blue crystals formed. The green supernatant was cannula filtered as before, concentrated under vacuum and placed in a $-27^{\circ} \mathrm{C}$ freezer again. This time, air-, moisture- and temperature-sensitive, colorless, X-ray quality crystals of $\mathbf{8}$ were formed in the flask, commingled with blue crystals as before. Because of the extreme sensitivity of $\mathbf{8}$, a yield could not be calculated, its melting point could not be measured, and it was not amenable to elemental analysis. Because of its tendency to decompose in solution, it could not be characterized spectroscopically, but only by single-crystal X-ray diffraction.

Synthesis of $\mathrm{Cu}_{2} \mathrm{C}_{2} \mathrm{O}_{4}(\mathrm{CyNC})_{4}(9)$. In a $10 \mathrm{~mL}$ round-bottom flask, $0.126 \mathrm{~g}$ oxalic acid dihydrate ( $1 \mathrm{mmol}$ ) was dissolved in $5 \mathrm{~mL}$ degassed 95\% ethanol with stirring. After dissolution, $0.142 \mathrm{~g}$ $\mathrm{Cu}_{2} \mathrm{O}(1 \mathrm{mmol})$ was added, followed immediately by $0.55 \mathrm{~mL}$ cyclohexyl isocyanide (CyNC, 4 $\mathrm{mmol}$ ), and the flask was stirred under nitrogen for $45 \mathrm{~min}$. The reaction mixture was filtered through a $0.45 \mu \mathrm{m}$ syringe filter under nitrogen, and the blue supernatant was concentrated under a flow of nitrogen to about half its original volume. The supernatant was placed in a $-27^{\circ} \mathrm{C}$ freezer overnight to yield a small amount of a white, crystalline precipitate. The precipitate was filtered and washed with ca. $10 \mathrm{~mL}$ of cold acetone, in portions, to yield 9 as a white powder (0.10 g, $15 \%), \mathrm{mp} 170-176^{\circ} \mathrm{C}$. Anal. Calcd for $\mathrm{C}_{34} \mathrm{H}_{56} \mathrm{Cu}_{2} \mathrm{~N}_{4} \mathrm{O}_{6}: \mathrm{C}, 54.89 ; \mathrm{H}, 7.59 ; \mathrm{Cu}, 17.08 ; \mathrm{N}$, 7.53. Found: $\mathrm{C}, 55.45 ; \mathrm{H}, 7.27 ; \mathrm{Cu}, 17.80 ; \mathrm{N}, 8.52 \% .{ }^{1} \mathrm{H} \mathrm{NMR}\left(\mathrm{CDCl}_{3}\right): \delta 1.34 \& 1.48(2$ br $\mathrm{m}$, $\mathrm{CH}_{2}$, total $16 \mathrm{H}$ ), 1.70 (br m, $\left.\mathrm{CH}_{2}, 16 \mathrm{H}\right), 1.89$ (br s, $\left.\mathrm{CH}_{2}, 8 \mathrm{H}\right), 3.62$ (br s, $\left.\mathrm{CH}, 4 \mathrm{H}\right) . \mathrm{IR}\left(\mathrm{cm}^{-1}\right)$ : 
$v_{\mathrm{N}=\mathrm{C}} 2159(\mathrm{~m}) ; v_{\mathrm{C}=\mathrm{O}} 1617(\mathrm{~s}) . \mathrm{X}$-ray quality crystals of this product (as the ethanol disolvate) could be obtained by simply omitting the acetone washing step described above.

Synthesis of $\mathrm{Cu}_{2} \mathrm{C}_{2} \mathrm{O}_{4}(\mathrm{cod})_{2}(\mathbf{1 0})$. In a $10 \mathrm{~mL}$ round-bottom flask, $0.099 \mathrm{~g}$ anhydrous oxalic acid (1 mmol) and $2 \mathrm{~mL}$ 1,5-cyclooctadiene (cod, $16 \mathrm{mmol}$ ) were dissolved in $1 \mathrm{~mL}$ degassed 95\% ethanol with stirring under nitrogen, after which $0.145 \mathrm{~g} \mathrm{Cu}_{2} \mathrm{O}(1 \mathrm{mmol})$ was added. This suspension was stirred for $15 \mathrm{~min}$, then filtered through a $0.45 \mu \mathrm{m}$ syringe filter. The green filtrate was placed in a $-27^{\circ} \mathrm{C}$ freezer for $4 \mathrm{~d}$ to yield a small amount of $\mathbf{1 0}$ as a waxy white, airand moisture-sensitive crystalline solid $(0.034 \mathrm{~g}, 8 \%)$. IR (Nujol, $\left.\mathrm{cm}^{-1}\right): v_{\mathrm{C}=\mathrm{O}} 1629$ (s). This solid decomposed in solution as well, preventing its NMR spectrum from being obtained. Because of the extreme sensitivity of $\mathbf{1 0}$, its melting point could not be obtained nor could an elemental analysis be performed. The crystals of this product obtained by cooling the filtered reaction mixture as above were of X-ray quality.

Synthesis of $\mathrm{Cu}_{2} \mathrm{C}_{2} \mathrm{O}_{4}(\mathrm{nbd})$ (11). In a $500 \mathrm{~mL}$ round-bottom flask, $58 \mathrm{~mL}$ norbornadiene (0.57 mol) was dissolved in $350 \mathrm{~mL}$ 95\% ethanol. The solution was degassed, after which $6.5 \mathrm{~g}$ anhydrous oxalic acid $(0.07 \mathrm{~mol})$ was added and dissolved. Lastly, $10.2 \mathrm{~g} \mathrm{Cu}_{2} \mathrm{O}(0.07 \mathrm{~mol})$ was added and the reaction mixture was stirred under nitrogen. After $12 \mathrm{~d}$, the reaction mixture had turned into a white suspension, and the $\mathrm{pH}$ of the supernatant (checked with damp $\mathrm{pH}$ paper) was neutral, indicating that all the oxalic acid had been consumed. The mixture was filtered on a Büchner funnel in a glovebox to give a white precipitate, which was washed with $3 \times 100 \mathrm{~mL}$ degassed $100 \%$ ethanol, transferred to a vacuum desiccator, and dried under vacuum to yield $\mathbf{1 1}$ as a white, relatively air-stable powder $(20.2 \mathrm{~g}, 92 \%), \mathrm{mp} \sim 260^{\circ} \mathrm{C}$ (dec.). Anal. Calcd for $\mathrm{C}_{9} \mathrm{H}_{8} \mathrm{Cu}_{2} \mathrm{O}_{4}: \mathrm{C}, 35.18 ; \mathrm{H}, 2.62 ; \mathrm{Cu}, 41.36$. Found: $\mathrm{C}, 34.31 ; \mathrm{H}, 2.69 ; \mathrm{Cu}, 37.04 \%$. This 
compound was insoluble in all common solvents, preventing solution NMR or single-crystal Xray diffraction from being carried out. It was therefore analyzed by solid-state NMR and powder X-ray diffraction. ${ }^{1} \mathrm{H}$ NMR (solid-state, MAS-CRAMPS): $\delta 1.9$ (br, $\mathrm{CH}_{2}$ ), 4.2 (br, bridgehead $\mathrm{CH}$ ), 5.1 (br, $\mathrm{C}=\mathrm{CH}) .{ }^{13} \mathrm{C}\left\{{ }^{1} \mathrm{H}\right\}$ NMR (solid-state, CPMAS): $\delta 51$ (bridgehead $\mathrm{CH}$ ), $61 \mathrm{ppm}$ $\left(\mathrm{CH}_{2}\right), 105 \& 110(\mathrm{CH}=\mathrm{CH}), 167\left(C_{2} \mathrm{O}_{4}\right)$. IR $\left(\mathrm{cm}^{-1}\right): v_{=\mathrm{C}-\mathrm{H}} 3019(\mathrm{w}) ; v_{\mathrm{C}=\mathrm{O}} 1628(\mathrm{~s}), 1617(\mathrm{~s})$.

Synthesis of Cu(di-(2-picolyl)amine) $\mathrm{C}_{2} \mathrm{O}_{4} \cdot \mathrm{H}_{2} \mathrm{O}$ (12). In a $10 \mathrm{~mL}$ round-bottom flask, $0.548 \mathrm{~g}$ di2-(1-di-2-picolylamino)propyl disulfide (dppds, $1 \mathrm{mmol})$ and $0.090 \mathrm{~g}$ anhydrous oxalic acid (1 mmol) were dissolved in $5 \mathrm{~mL} 95 \%$ ethanol under argon to give a light yellow solution. To this flask, $0.143 \mathrm{~g} \mathrm{Cu}_{2} \mathrm{O}(1 \mathrm{mmol})$ was added, and the reaction mixture was stirred for $1.5 \mathrm{~h}$. The supernatant turned dark green-brown, and a teal-colored precipitate was recovered by cannula filtration. This precipitate was washed via cannula with $5 \mathrm{~mL}$, then $2 \mathrm{~mL}$ degassed $95 \%$ ethanol. Since it appeared to be a $\mathrm{Cu}(\mathrm{II})$ compound, it was simply collected on a Hirsch funnel, washed with additional $95 \%$ ethanol (not degassed), and allowed to dry in air to yield $\mathbf{1 2}$ as a blue powder $\left(0.138 \mathrm{~g}, 37 \%\right.$, mp $\left.194-196^{\circ} \mathrm{C}\right)$. Anal. Calcd for $\mathrm{C}_{14} \mathrm{H}_{15} \mathrm{CuN}_{3} \mathrm{O}_{5}: \mathrm{C}, 45.59 ; \mathrm{H}, 4.10 ; \mathrm{Cu}$, 17.23; N, 11.39. Found: C, 45.50; H, 4.30; Cu, 17.63; N, 11.62\%. IR $\left(\mathrm{cm}^{-1}\right): v_{\mathrm{N}-\mathrm{H}}$ and $v_{\mathrm{O}-\mathrm{H}} 3430$ (w), $3192(\mathrm{w}) ; v_{\mathrm{C}=\mathrm{O}} 1622(\mathrm{~s}), 1602(\mathrm{~s})$. Crystals for single-crystal X-ray diffraction were grown by slow evaporation in air of a solution containing $6 \mathrm{mg}$ of this compound in $1 \mathrm{~mL}$ of $18 \mathrm{M} \Omega-\mathrm{cm}$ water.

\section{RESULTS AND DISCUSSION}

We have explored the scope of the synthesis of copper(I) oxalate complexes by direct reaction of $\mathrm{Cu}_{2} \mathrm{O}$ with oxalic acid in the presence of a much wider range of ligands than have hitherto been examined. Our reactions were usually run in $95 \%$ ethanol, though occasionally 
$100 \%$ ethanol was used. In certain cases where the complex was highly labile, the reaction was conducted in neat liquid ligand (i.e., avoiding extraneous solvent altogether). The general reaction is depicted in Scheme 1.

Scheme 1. General synthesis of copper(I) oxalate complexes with ligands L $(n=1,2)$.

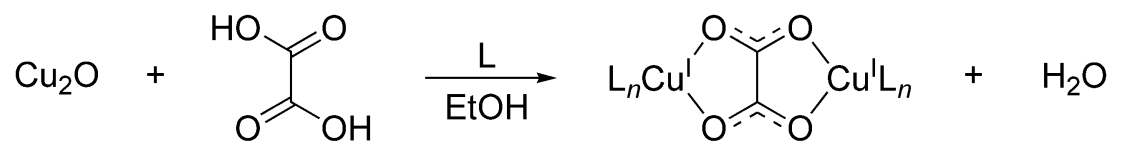

In almost all cases, it was possible to grow X-ray quality crystals of the compounds synthesized. Macroscopic characterization data from elemental analyses were mostly in agreement with the structures determined by X-ray diffraction methods, although there were minor deviations because of air-sensitivity of some of the compounds, difficulty in their complete combustion and inherent variability in the analytical methods for certain elements. The characteristic IR bands expected for the compounds were all present in the expected wavenumber ranges, in particular strong $\mathrm{C}=\mathrm{O}$ stretching vibrations between 1602 and $1637 \mathrm{~cm}^{-1}$ for compounds containing $\mathrm{C}_{2} \mathrm{O}_{4}{ }^{2-}$, and at $1668 \mathrm{~cm}^{-1}$ for $\mathrm{HC}_{2} \mathrm{O}_{4}{ }_{4}^{-}$.

Our structural characterizations revealed a rich variety of structural motifs that could be generated by this undemanding synthesis. Both the versatility of the $\mathrm{Cu}\left(\mu_{2}-\mathrm{C}_{2} \mathrm{O}_{4}\right) \mathrm{Cu}$ ligand platform (in terms of its structural variability, coordination geometry, and ability to bind a variety of ligands), and the ease of synthesizing this core structure reproducibly by this simple, green route were explored, as described in detail below. Lastly, our structural studies provided key insights into the mechanism of disproportionation of these $\mathrm{Cu}$ (I) oxalate complexes to $\mathrm{Cu}$ (II) oxalate and $\mathrm{Cu}^{0}$, and provided support for the existence of the thiolate form of a much-studied $\mathrm{N}_{x} \mathrm{~S}_{y}$ ligand, as will be seen in the following discussion. 


\section{Complexes with P ligands}

(i) $\mathrm{Cu}_{2}\left(\mathrm{C}_{2} \mathrm{O}_{4}\right)\left(\mathrm{PPh}_{3}\right)_{4}(\mathbf{1})$

The dinuclear compound $\mathrm{Cu}_{2}\left(\mathrm{C}_{2} \mathrm{O}_{4}\right) \mathrm{Cu}\left(\mathrm{PPh}_{3}\right)_{4}(\mathbf{1})$ has been synthesized by Gimeno et al . [7], Lang et al. [8] and by our own group [10]. Through a simpler synthesis, we have now obtained this compound in very high yield by reacting $\mathrm{Cu}_{2} \mathrm{O}$ with oxalic acid in $95 \%$ ethanol in the presence of $\mathrm{PPh}_{3}$. Our characterization data matched the previously reported values, except for the melting point, which was higher for our complex $\left(\sim 230^{\circ} \mathrm{C}\right.$, dec.) than that reported $\left(185^{\circ} \mathrm{C}\right)$ [8], possibly because it was a different polymorph. The structure of $\mathbf{1}$ is shown in Figure 1 , in which it can be seen that the central C-C bond in the oxalate ion is rotated out of the planar configuration (by $18.3^{\circ}$ ), whereas in crystals of both the dichloromethane disolvate and tetrasolvate, the oxalate group is planar. It appears, therefore, that the absence of solvent of crystallization in the crystal lattice allows the oxalate ion to adopt the lower energy $\mathrm{D}_{2}$ symmetry, as opposed to the planar $\mathrm{D}_{2 \mathrm{~h}}$ symmetry (which has higher energy due to electrostatic repulsions) imposed by crystal packing forces in crystals of the solvates [27].

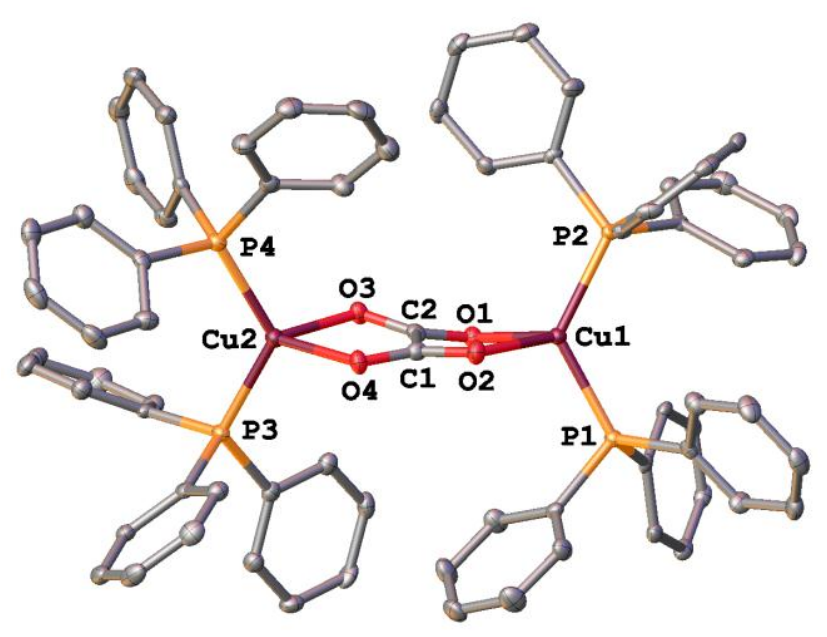


Figure 1. Structure of $\mathrm{Cu}_{2}\left(\mathrm{C}_{2} \mathrm{O}_{4}\right)\left(\mathrm{PPh}_{3}\right)_{4}(\mathbf{1})$, as determined by single-crystal X-ray crystallography. Hydrogen atoms are omitted for clarity, and thermal ellipsoids are at the 50\% probability level. Crystal data for $\mathrm{C}_{74} \mathrm{H}_{60} \mathrm{Cu}_{2} \mathrm{O}_{4} \mathrm{P}_{4}(1264.3 \mathrm{~g} / \mathrm{mol})$ : monoclinic; space group $P 2_{1} / c ; a=23.2188(15) \AA ; b=13.6885(8) \AA ; c=19.7387(14) \AA ; \beta=104.756(2)^{\circ} ; V=6066.7(7)$ $\AA^{3} ; Z=4$.

(ii) $\mathrm{Cu}_{2}\left(\mathrm{C}_{2} \mathrm{O}_{4}\right)(\text { dppe })_{2}(2)$

The white color of the reaction mixture at the end of this reaction indicated that the brickred $\mathrm{Cu}_{2} \mathrm{O}$ starting material had been entirely consumed. Compound $\mathbf{2}$ was nearly impossible to redissolve in common solvents, so it was analyzed by a variety of solid-state methods. Broad signals from both the aromatic and aliphatic ligand protons were observed in the solid-state ${ }^{1} \mathrm{H}$ NMR spectrum of this compound, at 6.0 and $1.2 \mathrm{ppm}$, respectively. Likewise, the solid-state ${ }^{13} \mathrm{C}\left\{{ }^{1} \mathrm{H}\right\}$ NMR spectrum showed the expected aromatic and aliphatic carbons of the dppe ligand at 132 and $25 \mathrm{ppm}$, respectively. Additionally, the oxalate carbons were observed at $171 \mathrm{ppm}$, consistent with a doubly deprotonated $\mathrm{C}_{2} \mathrm{O}_{4}{ }^{2-}$ species coordinated to a copper(I) center (shifted ca. 10 ppm upfield from uncoordinated oxalate) [1]. The ${ }^{31} \mathrm{P}$ NMR spectrum showed a single broad peak at -14 ppm, shifted upfield from the resonance of the free ligand (-12 ppm), typical of phosphorus ligands coordinated to copper [8]. The structure of this complex was solved and refined by powder X-ray diffraction techniques. The compound was found to be a dinuclear complex with bridging oxalate, with each copper $\kappa^{2}$-coordinated by one dppe ligand. Significant $\pi-\pi$ interactions between phenyl rings on adjacent molecules in the solid state accounted for the limited solubility of this compound, whose structure is shown in Figure 2, as determined by powder X-ray diffraction techniques to $2 \AA$ resolution. 


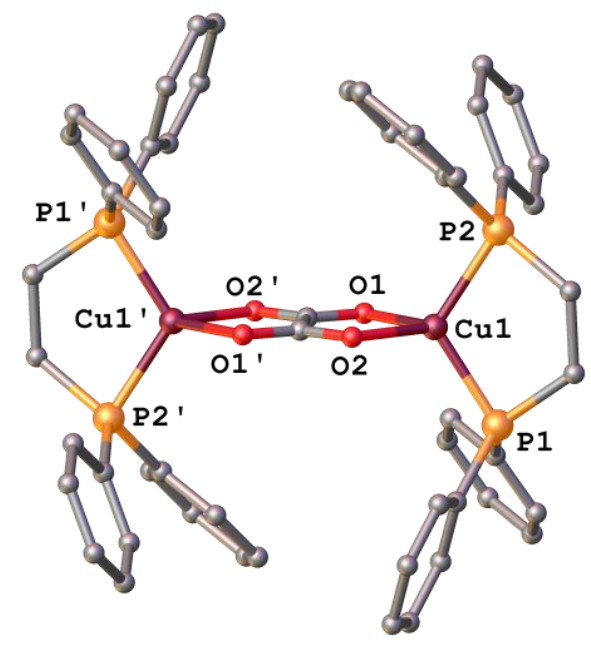

Figure 2. Structure of $\mathrm{Cu}_{2}\left(\mathrm{C}_{2} \mathrm{O}_{4}\right)(\text { dppe })_{2}(2)$, as determined by powder X-ray diffraction. Hydrogen atoms are omitted for clarity. Crystal data for $\mathrm{C}_{54} \mathrm{H}_{48} \mathrm{Cu}_{2} \mathrm{O}_{4} \mathrm{P}_{4}(1011.9 \mathrm{~g} / \mathrm{mol})$ : monoclinic; space group $P 2{ }_{1} / c ; a=11.760(29) \AA ; b=17.786(27) \AA ; c=10.319(13) \AA ; \beta=$ 101.33(9) $; V=2116(10) \AA^{3} ; Z=4$.

(iii) $\mathrm{Cu}_{2}\left(\mathrm{C}_{2} \mathrm{O}_{4}\right)\left(\mathrm{P}(\mathrm{OPh})_{3}\right)_{4}(3)$

When this reaction was carried out at room temperature, it was complete in a few hours, but the product was not a pure white, indicating that some degradation of the product had taken place, probably by disproportionation. The synthesis was therefore carried out at $0^{\circ} \mathrm{C}$ to yield a pure white product, air-stable when dry. In addition to the usual $\mathrm{C}=\mathrm{O}$ stretching vibration (at $\left.1627 \mathrm{~cm}^{-1}\right)$, the IR spectrum showed strong bands at 1186 and $1166 \mathrm{~cm}^{-1}$, which were attributed to C-O-P vibrations. The ${ }^{1} \mathrm{H}$ NMR spectrum showed the aromatic protons in the expected 7.0 $7.5 \mathrm{ppm}$ range, and there was a single peak in the ${ }^{31} \mathrm{P}$ NMR spectrum at $112 \mathrm{ppm}$, shifted upfield relative to the free ligand, as in $\mathbf{2}$ above. Crystals of this compound grown from ethanol/hexane 
were analyzed by single-crystal X-ray diffraction. The structure of $\mathbf{3}$ is shown in Figure 3, in which it can be seen that the compound was the predicted dinuclear complex with a bridging oxalate moiety and two triphenylphosphite ligands coordinated to each $\mathrm{Cu}(\mathrm{I})$ in much the same way as in $\mathbf{1}$. Here, however, the oxalate ligand is planar, and there is an inversion center in the middle of the C-C bond, giving the molecule $C_{i}$ symmetry. The two copper centers are not coplanar with the oxalate, but are arranged with one above and the other below the oxalate plane by about $13^{\circ}$.

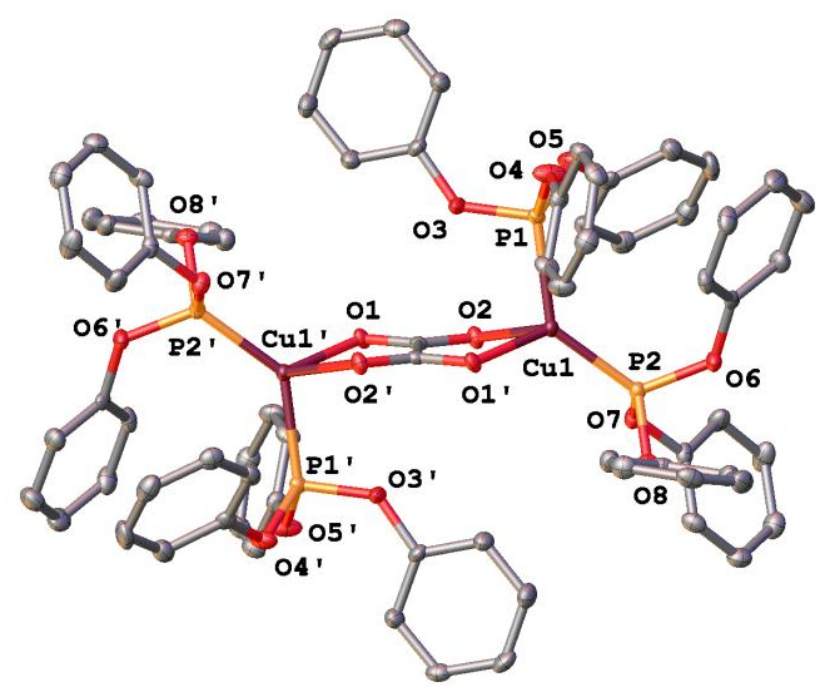

Figure 3. Structure of $\mathrm{Cu}_{2}\left(\mathrm{C}_{2} \mathrm{O}_{4}\right)\left(\mathrm{P}(\mathrm{OPh})_{3}\right)_{4}(3)$, as determined by single-crystal $\mathrm{X}$-ray crystallography. Hydrogen atoms are omitted for clarity, and thermal ellipsoids are at the $50 \%$ probability level. The molecule has point group symmetry $C_{i}$. Crystal data for $\mathrm{C}_{74} \mathrm{H}_{60} \mathrm{Cu}_{2} \mathrm{O}_{16} \mathrm{P}_{4}$ (1456.3 g/mol): monoclinic; space group $P 2_{1} / n ; a=10.4883(3) \AA ; b=13.9360(3) \AA ; ; c=$ 22.6144(7) $\AA ; \beta=97.772(2)^{\circ} ; V=3275.07(16) \AA^{3} ; Z=2$. Symmetry transformation used to generate equivalent (') atoms: $-x, 2-y, 1-z$.

Complexes with S ligands 
Prior to the synthesis of the copper(I) oxalate diisopropyl sulfide complex 4, many attempts were made in our laboratory to synthesize its simpler dimethyl sulfide analog. All were malodorous failures. As a result, we resorted to the more sterically protected diisopropyl sulfide. Although we were able to produce $\mathbf{4}$ at low temperatures, its air-sensitivity and thermal instability greatly limited its characterization. However, an infrared spectrum could be obtained by rapidly sandwiching a sample between salt plates and immediately measuring the spectrum. Though there was evidence of incipient decomposition in the spectrum, the expected strong $\mathrm{C}=\mathrm{O}$ stretching vibration could be seen at $1637 \mathrm{~cm}^{-1}$ as part of a broad group of oxalate carbonyl absorptions, as well as $\mathrm{O}-\mathrm{H}$ stretching bands at 3535 and $3449 \mathrm{~cm}^{-1}$. In the structure of 4 determined by single-crystal $\mathrm{X}$-ray diffraction, the $\mathrm{Cu}_{2} \mathrm{C}_{2} \mathrm{O}_{4}$ core is planar, with an inversion center in the center of the oxalate $\mathrm{C}-\mathrm{C}$ bond, implying $C_{i}$ symmetry for the molecule. Each oxygen center also acts as a hydrogen bond acceptor to one water molecule. The presence of water molecules in such intimate contact with the copper(I) oxalate complex in this structure and in 6, below, signals that these complexes are relatively stable towards hydrolysis in the absence of air (which causes the well-known oxidation $4 \mathrm{Cu}^{+}+\mathrm{O}_{2}+4 \mathrm{H}^{+} \rightarrow 4 \mathrm{Cu}^{2+}+2 \mathrm{H}_{2} \mathrm{O}$ ), explaining why $95 \%$ ethanol worked well as a solvent in this general synthetic method. The two $\mathrm{Cu}^{\mathrm{I}}$ centers are each coordinated to two ${ } \operatorname{Pr}_{2} \mathrm{~S}$ ligands in a distorted tetrahedral configuration, as in $\mathbf{1}$ and $\mathbf{2}$. 


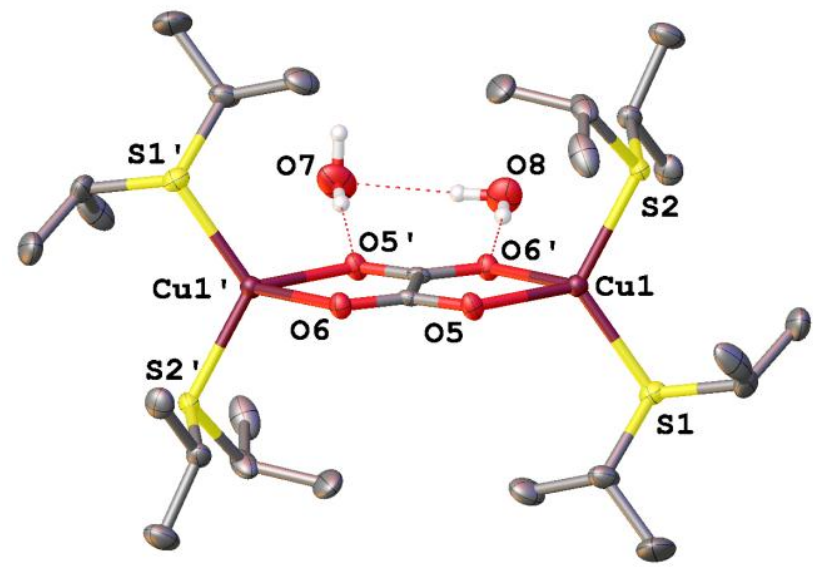

Figure 4. Structure of $\mathrm{Cu}_{2}\left(\mathrm{C}_{2} \mathrm{O}_{4}\right)\left(\mathrm{iPr}_{2} \mathrm{~S}\right)_{4} \cdot 4 \mathrm{H}_{2} \mathrm{O}$ (4) as determined by single-crystal X-ray crystallography. Two water molecules and all hydrogen atoms are omitted for clarity, except for those engaged in significant hydrogen-bonding interactions (dashed lines), and thermal ellipsoids are at the $50 \%$ probability level. Hydrogen atoms shown are in calculated positions. The molecule has point group symmetry $C_{i}$. Crystal data for $\mathrm{C}_{26} \mathrm{H}_{64} \mathrm{Cu}_{2} \mathrm{O}_{8} \mathrm{~S}_{4}(760.1 \mathrm{~g} / \mathrm{mol})$ : monoclinic; space group $P 2{ }_{1} / c ; a=9.3259(10) \AA ; b=12.5884(12) \AA ; c=16.8061(16) \AA ; \beta=$ 99.075(3) $; V=1948.3(3) \AA^{3} ; Z=2$. Symmetry transformation used to generate equivalent (') atoms: $-x, 1-y, 1-z$.

The green crystals of complex $\mathbf{5}$ that formed by disproportionation during crystallization of 4 were also structurally characterized. This compound, bis(bis(isopropylsulfido)copper(I))- $\mu$ bisoxalatocuprate(II), contains a central square planar bisoxalatocuprate(II) core that bridges two $\mathrm{Cu}^{\mathrm{I}}\left(\mathrm{iPr}_{2} \mathrm{~S}\right)_{2}$ moieties. The entire $\mathrm{Cu}^{\mathrm{I}}-\mathrm{C}_{2} \mathrm{O}_{4}-\mathrm{Cu}^{\mathrm{II}}-\mathrm{C}_{2} \mathrm{O}_{4}-\mathrm{Cu}^{\mathrm{I}}$ core structure is essentially planar, as in solid copper(II) oxalate, which is known to consist of infinite linear chains of this geometry [28]. However, unlike solid $\mathrm{CuC}_{2} \mathrm{O}_{4}$, in which there are bonding interactions between octahedral $\mathrm{Cu}^{\mathrm{II}}$ centers and oxygens on neighboring chains, the square planar $\mathrm{Cu}^{\mathrm{II}}$ centers in this complex do not 
have any close contacts in the crystal structure besides the oxalate oxygens to which they are coordinated because of the bulky isopropyl groups on the $\mathrm{Cu}^{\mathrm{I}}\left(\mathrm{Pr}_{2} \mathrm{~S}\right)_{2}$ endcaps.

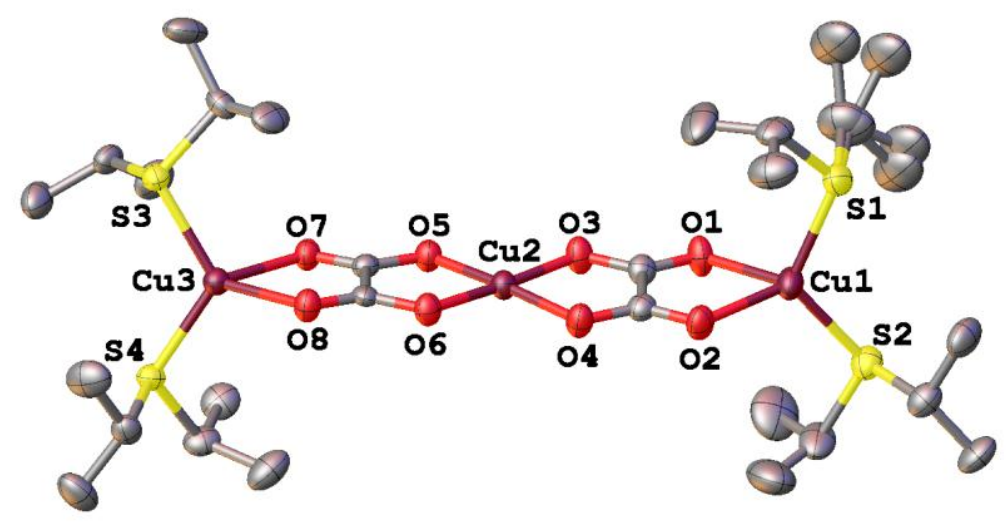

Figure 5. Structure of $\mathrm{Cu}_{3}\left(\mathrm{C}_{2} \mathrm{O}_{4}\right)_{2}\left(\mathrm{iPr}_{2} \mathrm{~S}\right)_{4}(\mathbf{5})$, as determined by single-crystal $\mathrm{X}$-ray crystallography. Hydrogen atoms are omitted for clarity, and thermal ellipsoids are at the $50 \%$ probability level. Here, $\mathrm{Cu} 1$ and $\mathrm{Cu} 3$ are in the +1 oxidation state, and $\mathrm{Cu} 2$ is in the +2 oxidation state. Crystal data for $\mathrm{C}_{28} \mathrm{H}_{56} \mathrm{Cu}_{3} \mathrm{O}_{8} \mathrm{~S}_{4}(839.6 \mathrm{~g} / \mathrm{mol})$ : monoclinic; space group $P 2_{1} / c ; a=$ 13.9870(18) $\AA ; b=8.6847(11) \AA ; c=32.178(4) \AA ; \beta=94.393(2)^{\circ} ; V=3897.3(9) \AA^{3} ; Z=4$.

The structure of this mixed-valence compound, intermediate between that of a copper(I) oxalate complex and the structure of copper(II) oxalate, suggests a mechanism for the disproportionation of copper(I) oxalate complexes $\mathrm{Cu}_{2} \mathrm{C}_{2} \mathrm{O}_{4}(\mathrm{~L})_{2}$ in general. This reaction likely proceeds via formation of ever longer concatenated $\mathrm{CuC}_{2} \mathrm{O}_{4}$ segments with $\mathrm{Cu}^{\mathrm{II}}$ centers in a bisoxalatocuprate(II)-type geometry, endcapped with $\mathrm{Cu}^{\mathrm{I}} \mathrm{L}_{2}$ moieties, resulting eventually in copper(II) oxalate and $\mathrm{Cu}^{0}$, concomitant with the release of free ligand. This process is summarized in Scheme 2, in which the first step is the well-known equilibrium of copper(I) complexes in solution with free ligand. This scheme suggests a mechanism for the frequent, dispiriting formation of brownish suspensions (probably mixtures of $\mathrm{Cu}^{0}$ and the highly insoluble 
copper(II) oxalate produced by this disproportionation) in the reaction between $\mathrm{Cu}_{2} \mathrm{O}$ and oxalic acid in the presence of ligand, noted by ourselves and other workers.

Scheme 2. Disproportionation of $\mathrm{Cu}_{2} \mathrm{C}_{2} \mathrm{O}_{4}(\mathrm{~L})_{2 n}(n=1,2)$ complexes by formation of ever longer $\mathrm{Cu}(\mathrm{I}) / \mathrm{Cu}(\mathrm{II})$ mixed-valence oxalates, leading ultimately to $\mathrm{CuC}_{2} \mathrm{O}_{4}, \mathrm{Cu}^{0}$ and free ligand $\mathrm{L}$.

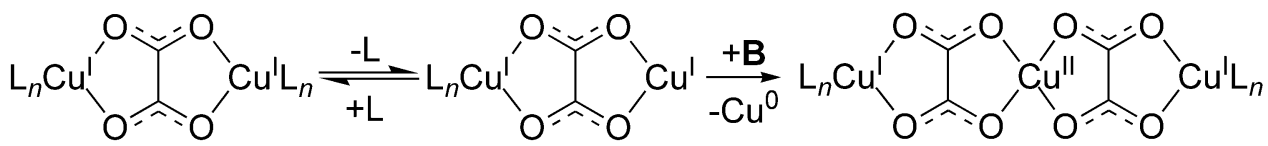

A

B

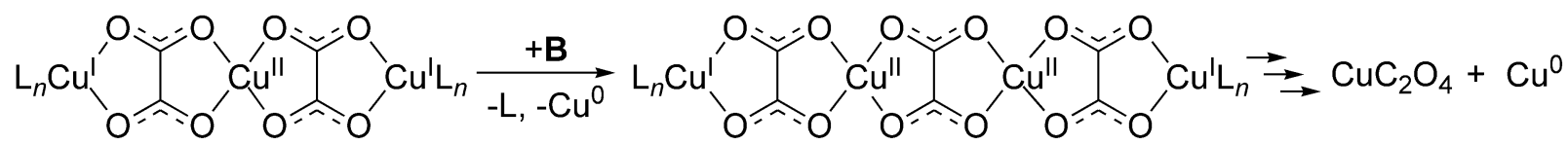

(ii) $\mathrm{Cu}_{2}(\mathrm{tu})_{6} \mathrm{C}_{2} \mathrm{O}_{4} \cdot 2 \mathrm{H}_{2} \mathrm{O}(\mathbf{6})$

Structurally characterized copper-thiourea complexes are numerous -53 are in the Cambridge Structural Database (CSD) at the time of this writing - and thiourea is known for its different modes of coordination to copper, though always through sulfur. We were interested to ascertain whether this ligand would form the usual dinuclear copper(I) oxalate complex with two thiourea ligands $\kappa^{1}$-coordinated to each metal center. $\mathrm{As} \mathrm{Cu}(\mathrm{I})$ thiourea complexes have long been known to be stable towards air and water [29], this reaction could be conducted without detriment in air. The $\mathrm{Cu}_{2} \mathrm{O}$ dissolved almost completely upon reaction with oxalic acid in $95 \%$ ethanol to produce a stable, colorless solution. At the end of the reaction, this solution likely contained a mixture of $\mathrm{Cu}(\mathrm{I})$ thiourea complexes. Only a small quantity of the ionic complex bis $\left(\mu_{2}\right.$-thiourea) tetrakis(thiourea) dicopper(I) oxalate (6) precipitated out, probably because it was the least soluble of the various species in solution. The infrared spectrum of this compound showed (besides the expected strong $\mathrm{C}=\mathrm{O}$ stretch at $1611 \mathrm{~cm}^{-1}$ ), a significant $\mathrm{C}=\mathrm{S}$ stretch at 
$1396 \mathrm{~cm}^{-1}$ and a number of O-H and N-H stretches between 3170 and $3410 \mathrm{~cm}^{-1}$. The solid-state ${ }^{1} \mathrm{H}$ NMR spectrum showed only two broad peaks at 0.3 and $6.3 \mathrm{ppm}$, corresponding to protons of water and thiourea $\mathrm{NH}_{2}$, respectively, while the ${ }^{13} \mathrm{C}\left\{{ }^{1} \mathrm{H}\right\}$ spectrum contained only the thiourea $\mathrm{C}=\mathrm{S}$ and oxalate carbon signals at 165 and $181 \mathrm{ppm}$, respectively. The crystal structure of 6 revealed that thiourea is present in both monodentate and bridging modes: two tu units bridge two copper centers, and two more monodentate tu units are attached to each of the centers, forming a $\left[\mathrm{Cu}_{2}(\mathrm{tu})_{6}\right]^{2+}$ complex with separate oxalate counterions. The $\left[\mathrm{Cu}_{2}(\mathrm{tu})_{6}\right]^{2+}$ complex ion has been reported in the literature [30], though not with this particular conformation, which has $C_{i}$ symmetry. The oxalate ion is not coordinated to copper in this compound, but is hydrogen bonded to cocrystallized water and to the $\mathrm{NH}_{2}$ groups of the thiourea ligands. The $\mathrm{Cu}-\mathrm{Cu}$ distance in this complex is $2.669 \AA$ (compared to $2.40 \AA$ in metallic copper), but since $\mathrm{Cu}^{\mathrm{I}}$ is a $d^{10}$ ion and this is a bridged complex, a metal-metal bond between the copper centers can be ruled out [31]. The entire crystal structure is held together rigidly by an extensive 3-D network of hydrogen bonds among the amine nitrogens, oxalate and water of crystallization, accounting for the compound's poor solubility.

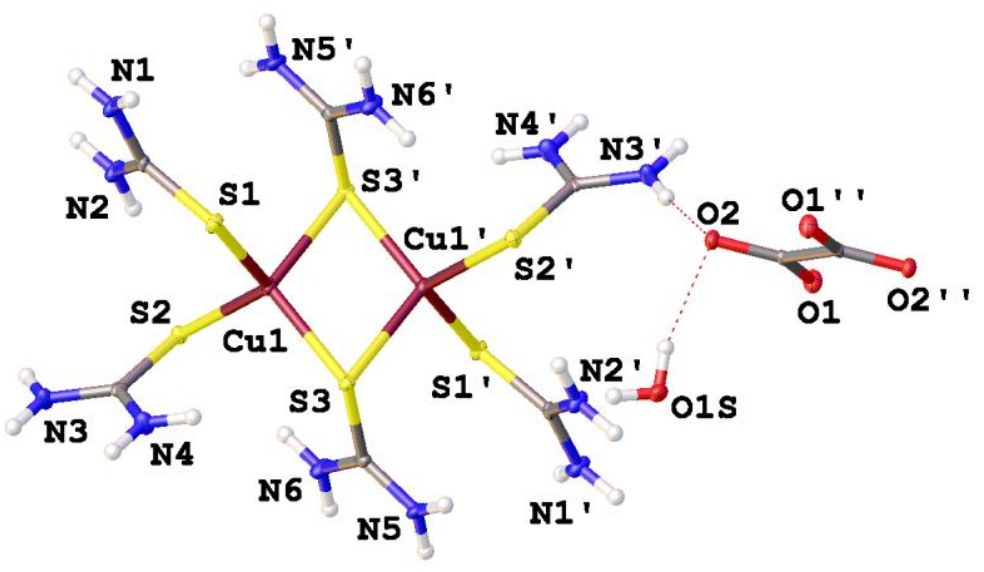


Figure 6. Structure of $\mathrm{Cu}_{2}(\mathrm{tu})_{6} \mathrm{C}_{2} \mathrm{O}_{4} \cdot 2 \mathrm{H}_{2} \mathrm{O}(\mathbf{6})$ as determined by single-crystal X-ray

crystallography. Hydrogen atoms are shown in calculated positions, and thermal ellipsoids are at the $50 \%$ probability level. Significant hydrogen-bonding interactions are shown as dashed lines. The complex has point group symmetry $C_{i}$. Crystal data for $\mathrm{C}_{8} \mathrm{H}_{28} \mathrm{Cu}_{2} \mathrm{~N}_{12} \mathrm{O}_{6} \mathrm{~S}_{6}(707.9 \mathrm{~g} / \mathrm{mol})$ :

triclinic; space group $P \overline{1} ; a=5.8128(16) \AA ; b=9.560(3) \AA ; c=12.018(3) \AA ; \alpha=96.410(9)^{\circ} ; \beta$ $=92.889(9)^{\circ} ; \gamma=101.903(9)^{\circ} ; V=647.5(3) \AA^{3} ; Z=2$. Symmetry transformations used to generate equivalent (') atoms: $1-x,-y, 1-z$; and (") atoms: $2-x,-1-y, 2-z$.

\section{Complexes with $N$ ligands}

(i) $\mathrm{Cu}(\text { dmphen })_{2} \mathrm{HC}_{2} \mathrm{O}_{4}(7)$

This reaction resulted in a highly colored product, as did analogous reactions between $\mathrm{Cu}_{2} \mathrm{O}$ and oxalic acid in the presence of 2,2'-bipyridyl and 1,10-phenanthroline (the latter two reaction products were not characterized). The FTIR spectrum of the product (7) of the reaction with dmphen displayed a strong $\mathrm{C}=\mathrm{O}$ stretching band at $1668 \mathrm{~cm}^{-1}$ and a weak $\mathrm{O}-\mathrm{H}$ stretching band at $3384 \mathrm{~cm}^{-1}$, indicating the presence of the $\mathrm{HC}_{2} \mathrm{O}_{4}{ }^{-}$ion rather than $\mathrm{C}_{2} \mathrm{O}_{4}{ }^{2-}$. The ${ }^{1} \mathrm{H} \mathrm{NMR}$ spectrum of this compound contained the expected resonances from the $\mathrm{CH}_{3}$ groups of the dmphen at $2.48 \mathrm{ppm}$ and the usual three aromatic proton resonances at 7.90, 8.16 and $8.66 \mathrm{ppm}$, but the proton from $\mathrm{HC}_{2} \mathrm{O}_{4}{ }^{-}$could not be observed, as the spectrum was obtained in $\mathrm{CD}_{3} \mathrm{OD}$. Structural characterization of 7 revealed that the well-known bischelate complex ion $\left[\mathrm{Cu}(\mathrm{dmphen})_{2}\right]^{+}$was produced in this reaction, with hydrogen oxalate as the counterion, as expected, instead of a molecular complex with oxalate coordinated to copper. This result was likely due to the chelating nature and strong $\pi$ acidity of the dmphen ligand, which therefore had more favorable interactions with the soft $\mathrm{Cu}^{+}$than the harder oxalate. A closely related complex, 
$\mathrm{Cu}(\mathrm{dmphen}) \mathrm{HC}_{2} \mathrm{O}_{4}$, has been reported as the benzene solvate [32], but was not structurally characterized. In 7, the hydrogen oxalate ions are nonplanar and form infinite hydrogen bonded chains. There are also numerous $\pi-\pi$ interactions among the aromatic dmphen ligands, as expected. The complex ion itself shows the usual distorted tetrahedral arrangement of the dmphen nitrogens about the copper center, and owes its vivid orange color to the well-known MLCT transitions involving the low-lying $\pi^{*}$ orbitals of the dmphen ligand [33]. Judging from the similarity of 7 to the products formed in the analogous reactions with 2,2'-bipyridyl and 1,10-phenanthroline, the products were likely the corresponding bischelate complex ions as well.

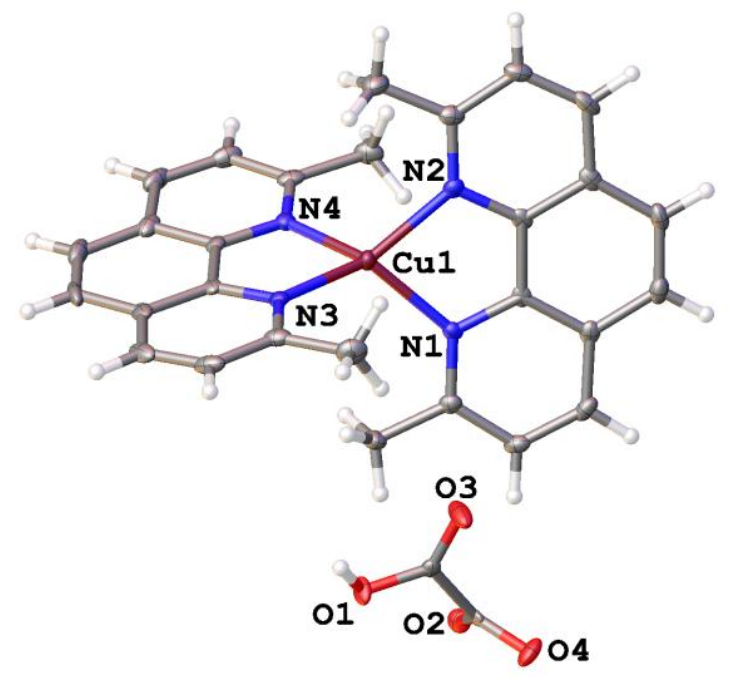

Figure 7. Structure of $\mathrm{Cu}(\mathrm{dmphen})_{2} \mathrm{HC}_{2} \mathrm{O}_{4}$ (7), as determined by single-crystal X-ray crystallography. Hydrogen atoms are shown in calculated positions, and thermal ellipsoids are at the $50 \%$ probability level. Crystal data for $\mathrm{C}_{30} \mathrm{H}_{25} \mathrm{CuN}_{4} \mathrm{O}_{4}(569.1 \mathrm{~g} / \mathrm{mol})$ : monoclinic; space group $P 2{ }_{1} / c ; a=14.5041(7) \AA ; b=17.0929(9) \AA ; c=10.4196(5) \AA ; \beta=92.496(2)^{\circ} ; V=$ $2580.7(2) \AA^{3} ; Z=4$.

(ii) $\mathrm{Cu}(\text { py })_{4} \mathrm{HC}_{2} \mathrm{O}_{4}$ (8) 
Pyridine, another good $\pi$ acid, also resulted in a mononuclear complex as opposed to the expected dinuclear complex with bridging oxalate. The tetrapyridine complex ion $\left[\mathrm{Cu}(\mathrm{py})_{4}\right]^{+}$ formed in this reaction has been structurally characterized, but only with non-coordinating counterions [34]. As was found previously, this ion was found to be tetrahedral in the crystal structure of our complex as well, with only slight distortions from ideal $\mathrm{N}-\mathrm{Cu}-\mathrm{N}$ bond angles. The hydrogen oxalate ions in the crystal structure are nonplanar and are arranged in hydrogen bonded dimers, not infinite chains. The complex was colorless, as expected, since the pyridine ligand lacks the low-lying $\pi^{*}$ molecular orbitals necessary for MLCT transitions.

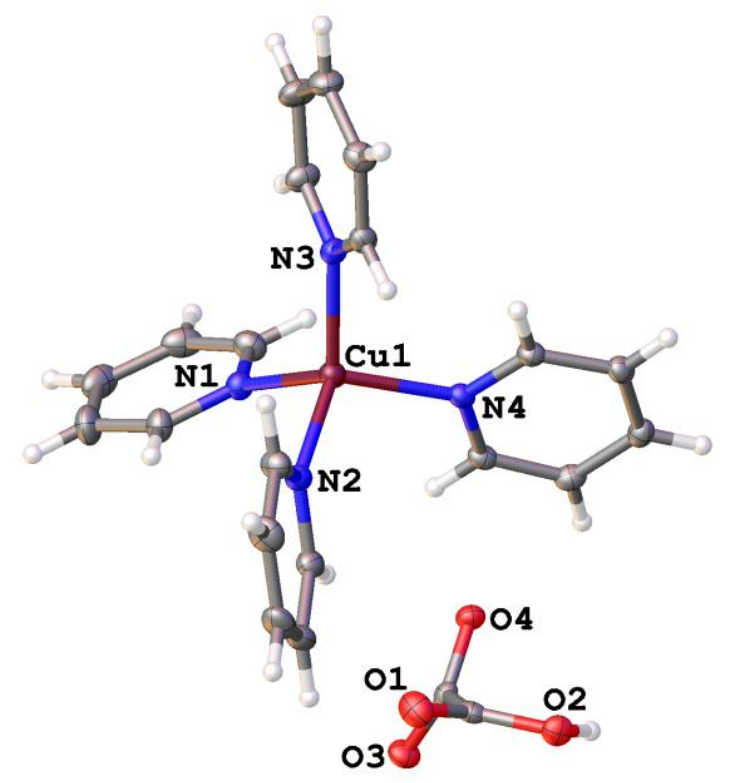

Figure 8. Structure of $\mathrm{Cu}(\mathrm{py})_{4} \mathrm{HC}_{2} \mathrm{O}_{4}(\mathbf{8})$, as determined by single-crystal X-ray crystallography. Hydrogen atoms are shown in calculated positions, and thermal ellipsoids are at the 50\% probability level. Crystal data for $\mathrm{C}_{22} \mathrm{H}_{21} \mathrm{CuN}_{4} \mathrm{O}_{4}(469.0 \mathrm{~g} / \mathrm{mol})$ : triclinic; space group $P \overline{1} ; a=$ 10.3189(5) $\AA ; b=10.4845(5) \AA ; c=10.9956(5) \AA ; \alpha=67.786(2)^{\circ} ; \beta=75.402(2)^{\circ} ; \gamma=$ $85.248(3)^{\circ} ; V=1065.65(9) \AA^{3} ; Z=2$. 
(iii) $\mathrm{Cu}_{2} \mathrm{C}_{2} \mathrm{O}_{4}(\mathrm{CyNC})_{4}(9)$

Doyle reported [4(a)] in a patent that the reaction between $\mathrm{Cu}_{2} \mathrm{O}$ and oxalic acid in the presence of cyclohexyl isocyanide in dichloromethane yielded $\mathrm{Cu}_{2} \mathrm{C}_{2} \mathrm{O}_{4}(\mathrm{CyNC})_{2}$, but no supporting data were provided, and the compound was not structurally characterized. Meyer $e t$ al. reported [2] that attempts to synthesize this complex in dichloromethane led to decomposition of the complex and provided the crystal structure of the $\left[\mathrm{Cu}(\mathrm{CNCy})_{4}\right]_{2}\left[\mathrm{Cu}\left(\mathrm{C}_{2} \mathrm{O}_{4}\right)_{2}\right]$ mixedvalence decomposition product, but no characterization data for the $\mathrm{Cu}(\mathrm{I})$ complex itself. Using a similar reaction to that of Doyle, we successfully synthesized and structurally characterized the molecular copper(I) oxalate complex with cyclohexyl isocyanide (9). The yield in this reaction was reduced by the competing hydrolysis of cyclohexyl isocyanide to cyclohexyl formamide in the acidic reaction medium.

Infrared spectroscopy showed characteristic $\mathrm{N} \equiv \mathrm{C}$ stretching vibrations at 2186 and 2159 $\mathrm{cm}^{-1}$, as well as the usual strong oxalate $\mathrm{C}=\mathrm{O}$ stretching vibration at $1617 \mathrm{~cm}^{-1}$. The $\mathrm{N} \equiv \mathrm{C}$ stretching vibrations are $30-50 \mathrm{~cm}^{-1}$ higher than in the free isocyanide ligand, indicative of strong $\sigma$ bonding and weak $\pi$ back-donation. In contrast to the stoichiometry reported by Doyle, we observed formation of the complex $\mathrm{Cu}_{2} \mathrm{C}_{2} \mathrm{O}_{4}(\mathrm{CyNC})_{4}$, whose structure was analogous to that of the phosphine complexes described earlier. Of all the $\mathrm{N}$ ligands we examined, this was the only one which produced a molecular copper(I) oxalate complex, which was attributed to the weak $\pi$ acidity of the isocyanide (the IR findings having shown that this ligand is chiefly bound to the copper(I) centers by $\sigma$ donation). The ${ }^{1} \mathrm{H}$ NMR spectrum confirmed the presence of the various $\mathrm{CH}_{2}$ and $\mathrm{CH}$ protons. 
In our synthesis, the compound $\mathbf{9}$ crystallized as the ethanol solvate, once again demonstrating the stability of these copper(I) oxalate complexes towards protic solvents in the absence of air. In the crystal structure, the molecule is located on an inversion center, and the $\mathrm{Cu}\left(\mathrm{C}_{2} \mathrm{O}_{4}\right) \mathrm{Cu}$ core is essentially planar, resulting in $C_{i}$ symmetry for the molecule. Two of the CyNC ligands (related to one another by inversion symmetry) in each molecule have the isocyanide group in the axial position, while this group is in the equatorial position in the other two CyNC ligands (also related by inversion symmetry), accounting for the two $\mathrm{N} \equiv \mathrm{C}$ bands seen in the infrared spectrum of this compound. The $\mathrm{N} \equiv \mathrm{C}$ bond lengths in this complex are 1.150(3) and 1.156(3) $\AA$, within the range of bond lengths for free isocyanides in the CSD $(1.13-1.16 \AA$ for a wide variety of alkyl isocyanides), and the $\mathrm{N} \equiv \mathrm{C}-\mathrm{C}$ angles are close to $180^{\circ}$ in both cases, further supporting a predominantly $\sigma$-bonding interaction between the isocyanide ligands and the copper centers.

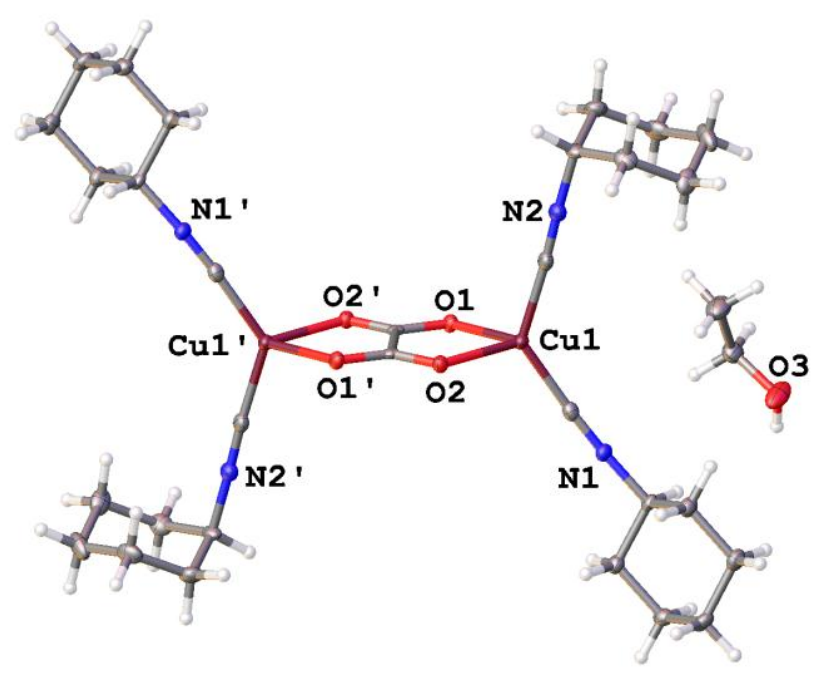

Figure 9. Structure of $\mathrm{Cu}_{2} \mathrm{C}_{2} \mathrm{O}_{4}(\mathrm{CyNC})_{4}(9)$ as the ethanol disolvate, determined by singlecrystal X-ray crystallography. Hydrogen atoms are shown in calculated positions, and thermal ellipsoids are at the $50 \%$ probability level. The molecule has point group symmetry $C_{i}$. Crystal 
data for $\mathrm{C}_{34} \mathrm{H}_{56} \mathrm{Cu}_{2} \mathrm{~N}_{4} \mathrm{O}_{6}(743.9 \mathrm{~g} / \mathrm{mol})$ : orthorhombic; space group Pbcn; $a=18.8800(6) \AA ̊ \AA ;=$ 9.6621(3) $\AA ; c=20.2576(6) \AA ; V=3695.4(2) \AA^{3}$. Symmetry transformation used to generate equivalent (') atoms: 1-x, 2-y, $-z$.

\section{Complexes with C ligands}

A large number of copper(I) oxalate complexes with unsaturated hydrocarbon ligands were claimed to have been synthesized by Doyle [4], but supporting analytical data were lacking, and there were certainly no structural studies. However, in their careful study of the reaction between $\mathrm{Cu}_{2} \mathrm{O}$ and oxalic acid with various ligands in anhydrous solvents, Köhler et al. presented the first structurally characterized copper(I) oxalate alkyne complexes [1]. The closely related alkene complexes were also reported in that work but were not elucidated structurally. The alkene complexes are, in general, considerably more unstable and difficult to handle, although the norbornadiene complex $\mathbf{1 1}$ is a notable exception (see below). We report here the first structurally characterized copper(I) oxalate alkene complexes, synthesized by this simple general method in ethanol.

(i) $\mathrm{Cu}_{2} \mathrm{C}_{2} \mathrm{O}_{4}(\operatorname{cod})_{2}(\mathbf{1 0})$

This reaction required a large excess of the cod ligand for stabilization of the complex in solution, probably due to facile dissociation of the ligand from the complex. A small amount of ethanol was used in the synthesis of complex $\mathbf{1 0}$ to promote ionization of oxalic acid, which would otherwise have been negligible in pure cod, a hydrocarbon. The fluxional nature of this complex resulted in its exquisite sensitivity to temperature, air and moisture, both in solution and in the solid state. The IR spectrum of this compound, as a Nujol mull, showed the expected oxalate $\mathrm{C}=\mathrm{O}$ stretch at $1629 \mathrm{~cm}^{-1}$. The crystal structure obtained by single-crystal X-ray 
diffraction revealed that there are two crystallographically independent molecules of $\mathbf{1 0}$ in the asymmetric unit, with very minor differences in geometry. In these molecules, the cod ligand adopts its usual tub shape, but only one alkene group in each ligand is coordinated to copper. The average distance between the coordinated alkene carbons and the copper centers is $2.02 \AA$. However, this distance increases to $2.63 \AA$ for the other alkene carbons of the same cod unit, indicating weak coordination of these carbons to the copper centers, if any. In addition, the $\mathrm{C}=\mathrm{C}$ bond distance in the non-coordinated alkene moiety is $1.34 \AA$, identical to that in the free cod ligand, and the $\mathrm{CH}_{2}-\mathrm{CH}=\mathrm{C}-\mathrm{H}$ torsion angles are close to $180^{\circ}$, again ruling out coordination of this double bond to copper. The copper centers in these complexes may therefore be viewed as pseudo three-coordinate (i.e., trigonal planar, the sums of the bond angles around each copper center being very nearly $360^{\circ}$ ), counting the coordinated alkene group as a single point of coordination. The central $\mathrm{Cu}\left(\mathrm{C}_{2} \mathrm{O}_{4}\right) \mathrm{Cu}$ core is essentially planar, and the structure of the complex as a whole is generally similar to that of the alkyne complexes reported previously [1].

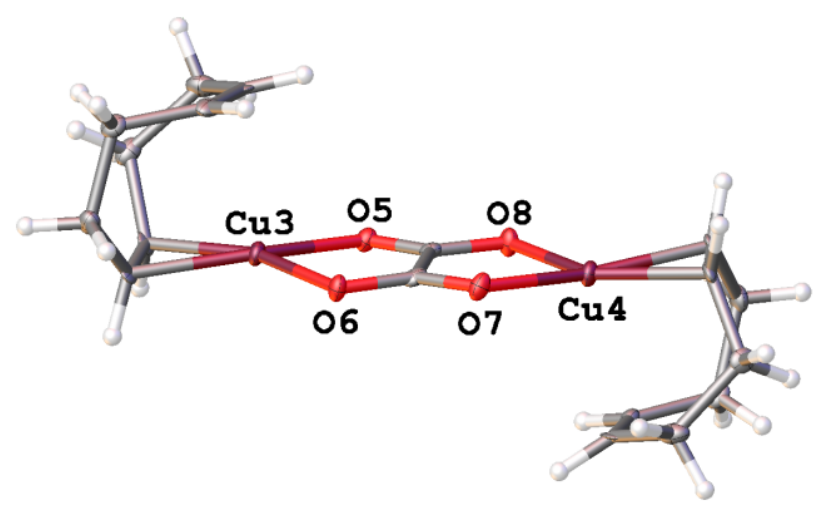

Figure 10. Structure of $\mathrm{Cu}_{2} \mathrm{C}_{2} \mathrm{O}_{4}(\operatorname{cod})_{2}(\mathbf{1 0})$ as determined by single-crystal X-ray crystallography. Hydrogen atoms are shown in calculated positions, and thermal ellipsoids are at the $50 \%$ probability level. Only one of the two molecules in the asymmetric unit is shown. 
Crystal data for $\mathrm{C}_{18} \mathrm{H}_{24} \mathrm{Cu}_{2} \mathrm{O}_{4}(431.5 \mathrm{~g} / \mathrm{mol})$ : monoclinic; space group $P 2{ }_{1} / c ; a=22.7399(11) \AA ;$ $b=6.4059(3) \AA ; c=23.4665(10) \AA ; \beta=94.944(2)^{\circ} ; V=3405.6(3) \AA^{3} ; Z=8$.

(ii) $\mathrm{Cu}_{2} \mathrm{C}_{2} \mathrm{O}_{4}$ (nbd) (11)

Unlike the cod complex above, the nbd complex was unusually temperature-, air- and moisture-stable, only turning faintly green over a few hours in air and storable indefinitely at room temperature in a desiccator. It was also insoluble in common solvents, suggesting strongly that the bidentate norbornadiene ligand had led to the formation of a polymeric structure. Infrared spectroscopy revealed the presence of alkene groups in this compound by a small but clearly visible $=\mathrm{C}-\mathrm{H}$ stretching vibration at $3019 \mathrm{~cm}^{-1}$ (in addition to the customary strong $\mathrm{C}=\mathrm{O}$ stretching bands at 1628 and $1617 \mathrm{~cm}^{-1}$ from the oxalate groups). The proton resonances of the alkene ligand were clearly visible as broad features in the solid-state NMR spectrum at $1.9 \mathrm{ppm}$ for the $\mathrm{CH}_{2}$ group, $4.2 \mathrm{ppm}$ for the bridgehead $\mathrm{CH}$, and $5.1 \mathrm{ppm}$ for the alkene $\mathrm{CH}$. While the ${ }^{13} \mathrm{C}\left\{{ }^{1} \mathrm{H}\right\}$ NMR spectrum showed the expected resonances for the bridgehead $\mathrm{CH}$ at $51 \mathrm{ppm}, \mathrm{CH}_{2}$ carbon at $61 \mathrm{ppm}$ and oxalate carbon at $167 \mathrm{ppm}$, the alkene carbons showed two distinct peaks at 105 and $110 \mathrm{ppm}$, indicating two different environments for these carbons in the solid state. The structure of this compound was solved by joint use of neutron and X-ray powder diffraction methods, and is shown in Figure 11. 


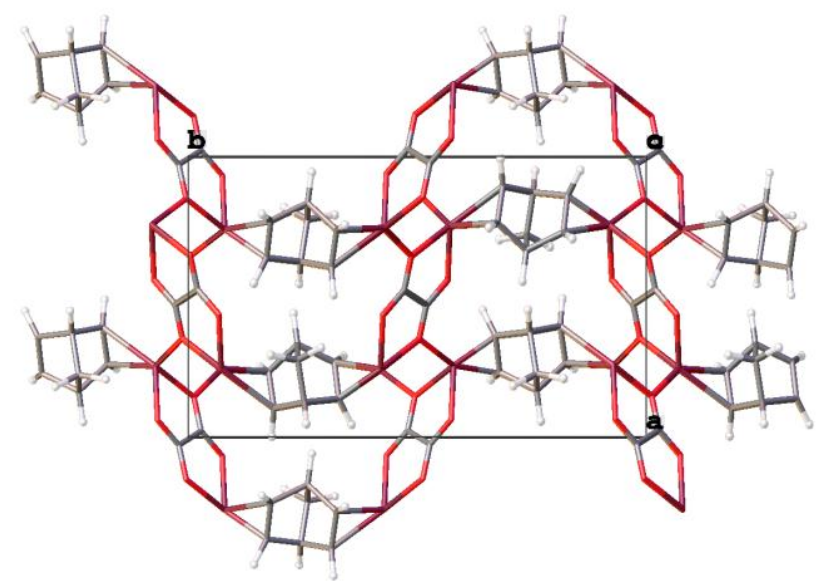

Figure 11. Structure of $\mathrm{Cu}_{2} \mathrm{C}_{2} \mathrm{O}_{4}(\mathrm{nbd})(\mathbf{1 1})$ as determined by joint neutron/X-ray powder diffraction methods (projection along crystallographic $c$ axis; unit cell shown). Copper is purple, oxygen is red, carbon is grey and hydrogen is white. Crystal data for $\mathrm{C}_{9} \mathrm{H}_{8} \mathrm{Cu}_{2} \mathrm{O}_{4}(307.3 \mathrm{~g} / \mathrm{mol})$ : orthorhombic; space group $P 2{ }_{12}{ }_{1} 2_{1} ; a=9.83351(13) \AA ; b=16.12147(32) \AA ; c=5.35779(9) \AA ;$ $V=849.373(30) \AA^{3} ; Z=4$.

The main structural feature of this compound is, as anticipated, infinite chains of $-\mathrm{Cu}\left(\mathrm{C}_{2} \mathrm{O}_{4}\right) \mathrm{Cu}-(\mathrm{nbd})$ - repeating units, shown in Figure 12. These chains are connected to each other by $\mathrm{Cu}-\mathrm{O}$ bonds, forming an infinite three-dimensional network. Each copper center is pentacoordinate (pseudotetrahedral), bonded to two alkene carbons of a norbornadiene ligand, two oxygens of a single oxalate anion, and also to an oxygen from an oxalate group on a neighboring chain in the network. In this structure, the two $\mathrm{Cu}-\mathrm{C}$ bond lengths are different, i.e., the interaction between a copper center and the two carbons of a coordinated double bond is not symmetric, as previously indicated by the presence of two alkene carbon resonances in the solidstate ${ }^{13} \mathrm{C}$ NMR spectrum of this complex. This peak splitting was not due to coupling with the spin-3/2 copper nuclei to which they were coordinated, as other well-characterized $\mathrm{Cu}(\mathrm{I})$ olefin complexes did not exhibit $\mathrm{Cu}-\mathrm{C}$ coupling in their ${ }^{13} \mathrm{C}$ NMR spectra [35], so it was ascribed to the 
two different $\mathrm{Cu}-\mathrm{C}$ bond distances (2.112 vs. $2.334 \AA$ and 1.979 vs. $2.073 \AA$ ) observed in the solid-state structure.

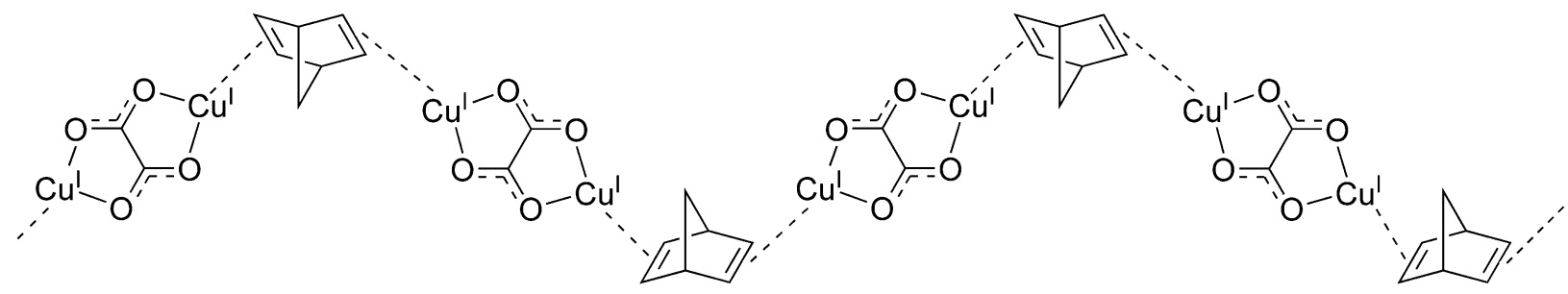

Figure 12. Structure of a single chain in the three-dimensional network polymer 11. Each copper center is actually pseudo four-coordinate, forming a bond to an oxalate oxygen on a neighboring chain (not shown in this diagram for simplicity) to generate a three-dimensional network solid.

Complex with mixed $N_{x} S_{y}$ ligand

$\mathrm{Cu}($ di-(2-picolyl)amine $) \mathrm{C}_{2} \mathrm{O}_{4} \cdot \mathrm{H}_{2} \mathrm{O}(\mathbf{1 2})$

An attempt was made to isolate the copper(I) oxalate complex with the mixed $\mathrm{N}_{x} \mathrm{~S}_{y}$ ligand dppds by allowing $\mathrm{Cu}_{2} \mathrm{O}$ to react with oxalic acid in ethanol in the presence of the ligand. This complex is of interest in bioinorganic chemistry [36, 37]. Although our goal was to obtain the copper(I) oxalate complex with the dppds ligand using our simple one-step synthesis, we instead isolated an air-stable blue powder, evidently a copper(II) compound, which was recrystallized from water. The IR spectrum of this compound showed, in addition to intense oxalate $\mathrm{C}=\mathrm{O}$ stretching bands at 1622 and $1602 \mathrm{~cm}^{-1}$, a pair of bands in the $\mathrm{N}-\mathrm{H} / \mathrm{O}-\mathrm{H}$ stretching region at 3430 and $3192 \mathrm{~cm}^{-1}$. Interestingly, the crystal structure of this blue compound revealed that it was not simply the copper(II) dppds complex, as might have been expected, but a smaller copper(II) di-(2-picolyl)amine oxalate complex (12), entirely devoid of sulfur, as shown in Figure 13. 


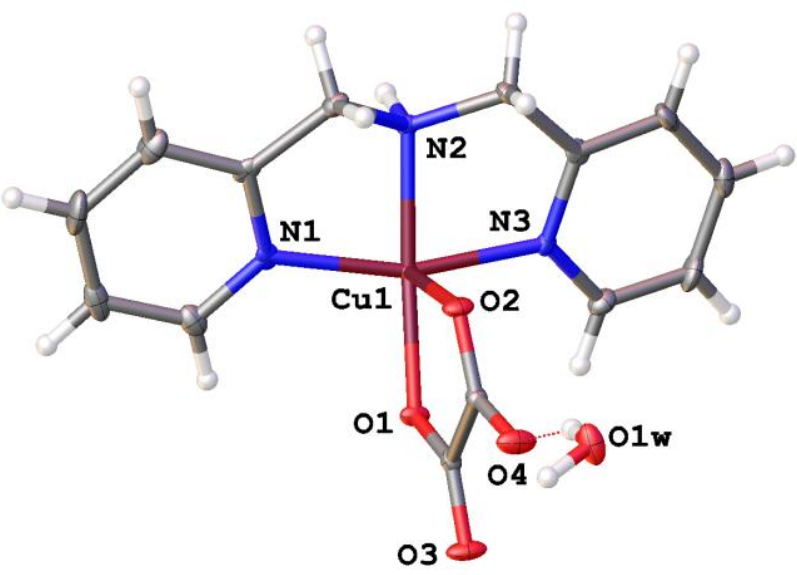

Figure 13. Structure of $\mathrm{Cu}\left(\mathrm{di}-(2-\right.$ picolyl)amine $) \mathrm{C}_{2} \mathrm{O}_{4} \cdot \mathrm{H}_{2} \mathrm{O}$ (12) as determined by single-crystal X-ray crystallography. Hydrogen atoms are shown in calculated positions, and thermal ellipsoids are at the $50 \%$ probability level. Crystal data for $\mathrm{C}_{14} \mathrm{H}_{15} \mathrm{CuN}_{3} \mathrm{O}_{5}(368.8 \mathrm{~g} / \mathrm{mol})$ : orthorhombic; space group Pbca; $a=18.5834(8) \AA ; b=8.3215(4) \AA ; c=19.1366(7) \AA ; V=2959.3(2) \AA^{3} ; Z=$ 8.

This finding may be rationalized in light of the recent report by Stack et al. [37(d)], who noted a solvent-dependent tautomerization equilibrium between $\mathrm{Cu}(\mathrm{I})$ disulfide (A) and $\mathrm{Cu}(\mathrm{II})$ thiolate (B) forms of the dppds complex, shown in Figure 14 (top). The $\mathrm{Cu}$ (II) form (B), being more polar, was probably the dominant form in our synthesis, which was carried out in $95 \%$ ethanol. The tertiary amine in $\mathbf{B}$ could be protonated by oxalic acid during the reaction, as depicted in Figure 14 (bottom). This protonation step would then lead to ready extrusion of propylene sulfide by an intramolecular $\mathrm{S}_{\mathrm{N}} 2$ attack. The vacant coordination site on the $\mathrm{Cu}(\mathrm{II})$ center would then be ripe for chelation by oxalate to yield the di-(2-picolyl)amine copper(II) oxalate complex 12, which was precisely what we observed. Since the presence of the thiolate form $\mathbf{B}$ is crucial for the intramolecular $\mathrm{S}_{\mathrm{N}} 2$ reaction to remove propylene sulfide and eventually 
form 12, our results further corroborate thiolate formation in copper complexes of this ligand, especially in polar solvents.
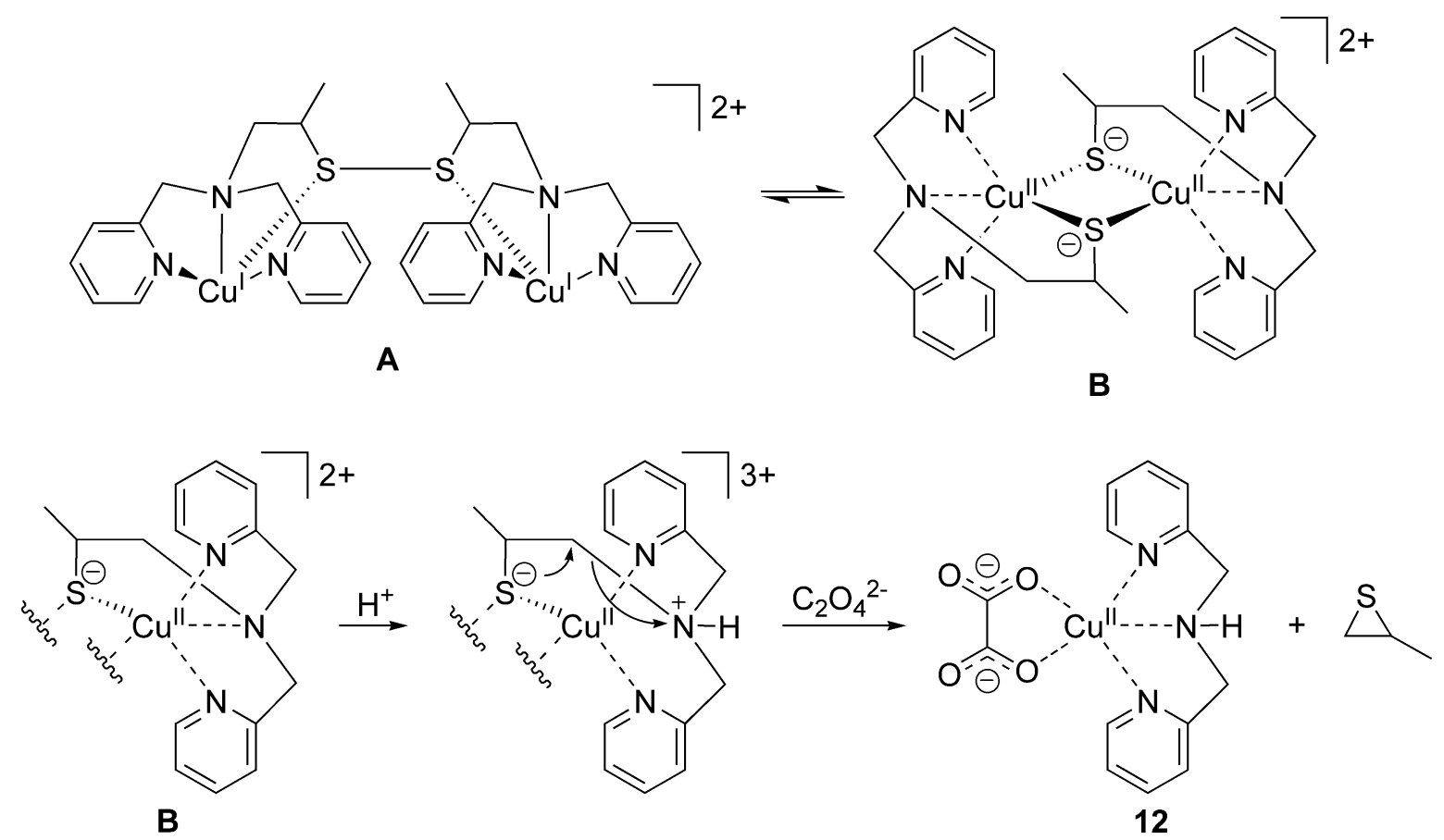

Figure 14. (top) Equilibrium between $\mathrm{Cu}(\mathrm{I})$ disulfide form (A) and $\mathrm{Cu}$ (II) thiolate form (B) of copper dppds complex in solution. (bottom) Proposed pathway for conversion of B (one-half of complex shown for simplicity) to di-(2-picolyl)amine copper(II) oxalate complex 12 under acidic conditions via (i) protonation of secondary amine and (2) nucleophilic $\mathrm{S}_{\mathrm{N}} 2$ attack by thiolate to form propylene sulfide. A second oxalate ion is $\kappa^{1}$-coordinated to the $\mathrm{Cu}(\mathrm{II})$ center in $\mathbf{1 2}$, but is omitted here for clarity.

In the solid-state structure of complex $\mathbf{1 2}$, each copper center is $\kappa^{3}$-coordinated by one molecule of di-(2-picolyl)amine, $\kappa^{2}$-coordinated by one planar oxalate anion, and $\kappa^{1}$-coordinated by a second oxalate ion (in the same plane as the first), which is in turn $\kappa^{2}$-coordinated to a neighboring copper center. Thus, a coordination polymer is formed from these octahedral $\mathrm{Cu}^{\mathrm{II}}$ centers connected by oxalate ions. Water molecules line the linear channels between these 
chains, each molecule engaging in two hydrogen bonds to oxalate groups on neighboring chains. Lastly, the secondary amine of the ligand is engaged in intrachain hydrogen bonding with the oxalate oxygen $\kappa^{1}$-coordinated to the next copper center in the chain, accounting for the zig-zag geometry of this polymer. These numerous hydrogen bonds greatly stabilize the chains of this compound in the solid state, leading to the facile formation of rather large crystals from aqueous solution, easily exceeding $0.5 \mathrm{~cm}$ in size.

\section{CONCLUSIONS}

We have explored in detail, with structural characterization in every case, the synthesis of a variety of copper(I) oxalate complexes using a very simple reaction methodology, in as "green" a manner as possible. Using a breadth of ligands, this uncomplicated route allowed us to access quite a number of dinuclear $\mathrm{Cu}(\mathrm{I})$ oxalate complexes, most of which were new, others of which were reported in the (patent) literature but poorly characterized. Our results have made it abundantly clear that the $\mathrm{Cu}\left(\mu_{2}-\mathrm{C}_{2} \mathrm{O}_{4}\right) \mathrm{Cu}$ moiety is quite a versatile ligand platform. In some cases (with pyridine and related ligands), the mononuclear complex ion $\left[\mathrm{CuL}_{n}\right]^{+}$was produced. During the course of our investigations into the scope of this reaction, we have uncovered a mechanism for the ready disproportionation of these copper(I) oxalate complexes to $\mathrm{CuC}_{2} \mathrm{O}_{4}$ and $\mathrm{Cu}^{0}$, as well as a novel reaction pathway of a copper $\mathrm{N}_{x} \mathrm{~S}_{y}$ complex of current interest.

\section{ACKNOWLEDGMENTS}

This project was supported by grants from the University of West Florida through the Office of Research and Sponsored Programs and the Office of Undergraduate Research. RFM acknowledges scholarship support from the CAPES Foundation, Brazil. Use of the Advanced Photon Source at Argonne National Laboratory was supported by the U. S. Department of 
Energy, Office of Science, Office of Basic Energy Sciences, under Contract No. DE-AC0206CH11357. We also thank Dr. Amy A. Sarjeant for conducting preliminary powder diffraction measurements during the 2013 ACA Summer Course in Crystallography at Northwestern University.

\section{APPENDIX A. SUPPLEMENTARY MATERIAL}

Spectra and crystallographic information.

\section{REFERENCES}

[1] K. Köhler, J. Eichhorn, F. Meyer, D. Vidovic, Organometallics 22 (2003) 4426-4432.

[2] J. Teichgräber, S. Dechert, F. Meyer, J. Organomet. Chem. 690 (2005) 5255-5263.

[3] R. Angamuthu, P. Byers, M. Lutz, A.L. Spek, E. Bouwman, Science 327 (2010) 313-315.

[4] (a) G. Doyle, Removal of CO and Unsaturated Hydrocarbons from Gas Streams Using Copper Oxalate Complexes, US Patent 4347066, August 31, 1982. (b) G. Doyle, Copper Oxalate Complexes, US Patent 4387055 June 7, 1983.

[5] A.P. Glaskova, Explosivstoffe 21 (1973) 137-145.

[6] L.C. Daniels, J. Am. Chem. Soc. 37 (1915) 1167-1171.

[7] J. Díez, S. Falagán, P. Gamasa, J. Gimeno, Polyhedron 7 (1988) 37-42.

[8] A. Jakob, T. Rüffer, P. Ecorchard, B. Walfort, K. Körbitz, S. Frühauf, S.E. Schulz, T. Gessner, H. Lang, Z. Anorg. Allg. Chem. 636 (2010) 1931-1940. 
[9] W. Frosch, S. Back, G. Rheinwald, K. Köhler, L. Zsolnai, G. Huttner, H. Lang, Organometallics 19 (2000) 5769-5779.

[10] A.D. Royappa, J.A. Golen, A.L. Rheingold, A.T. Royappa, Acta Cryst. E69 (2013) m126.

[11] A.T. Royappa, J.R. Stepherson, O.D. Vu, A.D. Royappa, C.L. Stern, P. Müller, Acta Cryst. E69 (2013) m544.

[12] A.M. Willcocks, T. Pugh, S.D. Cosham, J. Hamilton, S.L. Sung, T. Heil, P.R. Chalker, P. A. Williams, G. Kociok-Köhn, A.L. Johnson, Inorg. Chem. 54 (2015) 4869-4881.

[13] E. De Barry Barnett, C.L. Wilson, Inorganic Chemistry, third ed., Longmans, Green and Co., London, 1957, p. 257.

[14] K. Köhler, F. Meyer, Dicopper(I) Oxalate Complexes for Use as Precursor Substances in Metallic Copper Deposition, US Patent 7169947, January 30, 2007.

[15] G.S. Girolami, T.B. Rauchfuss, R.J. Angelici, Synthesis and Technique in Inorganic Chemistry, third ed., University Science Books, Sausalito, 1999, p. 85.

[16] G. Courbion, G. Ferey, J. Solid State Chem. 76 (1988) 426-431.

[17] L. O’Neill, Powder Diffr. 28 (2013) 137-148. (see p. 140 for K $\alpha 2$ stripping and p. 142 for PowDLL).

[18] A. Altomare, C. Cuocci, C. Giacovazzo, A. Moliterni, R. Rizzi, N. Corriero, A. Falcicchio, J. Appl. Crystallogr. 46 (2013) 1231-1235. 
[19] A. Altomare, C. Giacovazzo, A. Guagliardi, A.G.G. Moliterni, R. Rizzi, P.-E. Werner, J. Appl. Crystallogr. 33 (2000) 1180-1186.

[20] (a) V. Favre-Nicolin, R. Černý, J. Appl. Crystallogr. 35 (2002) 734-743. (b) V. FavreNicolin, R. Černý, Z. Kristallogr. 219 (2004) 847-856.

[21] J. Pannetier, J. Bassas-Alsina, J. Rodríguez-Carvajal, V. Caignaert, Nature 346 (1990) 343-345.

[22] A.B. Larson, R.B. Von Dreele, General Structure Analysis System (GSAS) - Los Alamos National Laboratory Report LAUR 86-748, Los Alamos, 2000.

[23] A. Boultif, D. Louër, J. Appl. Crystallogr. 37 (2004) 724-731.

[24] T. Roisnel, J. Rodríguez-Carvajal, Mater. Sci. Forum 378-381 (2001) 118-123.

[25] (a) G.M. Sheldrick, SHELX-97 - Computer Program for Crystal Structure Refinement, University of Göttingen, Göttingen, 1997. (b) G.M. Sheldrick, Acta Crystallogr., Sect. A $64(2008) 112-122$.

[26] O.V. Dolomanov, L.J. Bourhis, R.J. Gildea, J.A.K. Howard, H. Puschmann, J. Appl. Cryst. 42 (2009) 339-341.

[27] T. Clark, P.v.R. Schleyer, J. Comput. Chem. 2 (1981) 20-29.

[28] (a) A.N. Christensen, B. Lebech, N.H. Andersen, J.-C. Grivel, Dalton Trans. 43 (2014) 16754-16768. (b) H. Fichtner-Schmittler, Cryst. Res. Technol. 19 (1984) 1225-1230. (c) A. Gleizes, F. Maury, J. Galy, Inorg. Chem. 19 (1980) 2074-2078. (d) A. Michalowicz, 
J.J. Girerd, J. Goulon, Inorg. Chem. 18 (1979) 3004-3010. (e) H. Schmittler, Monatsber. D. Akad. Wiss. Berlin 10 (1968) 581-604.

[29] (a) L. Zeng, E.W. Miller, A. Pralle, E.Y. Isacoff, C.J. Chang, J. Am. Chem. Soc. 128 (2006) 10-11 (see Supporting Information). (b) J.G. Frost, M.B. Lawson, W.G. McPherson, Inorg. Chem. 15 (1976) 940-943. (c) E.I. Onstott, H.A. Laitinen, J. Am. Chem. Soc. 72 (1950) 4724-4728.

[30] (a) P. Bombicz, I. Mutikainen, M. Krunks, T. Leskelä, J. Madarász, L. Niinistö, Inorg. Chim. Acta 357 (2004) 513-525. (b) K. Johnson, J.W. Steed, J. Chem. Soc., Dalton Trans. (1998) 2601-2602. (c) M. Van Meerssche, R. Kamara, J.P. Declercq, G. Germain, Bull. Soc. Chim. Belg. 91 (1982) 547-552. (d) I.F. Taylor, M.S. Weininger, E.L. Amma, Inorg. Chem. 13 (1974) 2835-2842. (e) F. Hanic, E. Ďurčanská, Inorg. Chim. Acta 3 (1969) 293-298.

[31] F.A. Cotton, G. Wilkinson, C.A. Murillo, M. Bochmann, Advanced Inorganic Chemistry, sixth ed., John Wiley \& Sons, New York, 1999, p. 861.

[32] W.-L. Kwik, K.-P. Ang, J. Chem. Soc., Dalton Trans. (1981) 452-455.

[33] (a) E.M. Kober, T.J. Meyer, Inorg. Chem. 24 (1985) 106-108. (b) A.A. Del Paggio, D.R. McMillin, Inorg. Chem. 22 (1983) 691-692. (c) G.A. Crosby, Acc. Chem. Res. 8 (1975) 231-238.

[34] (a) K. Nilsson, Å. Oskarsson, Acta Chem. Scand. A 36 (1982) 605-610. (b) G. Horvat, T. Portada, V. Stilinović, V. Tomišić, Acta Cryst. E63 (2007) m1734. 
[35] (a) Personal communication, Andrew R. Barron. (b) See also D. Knol, N.J. Koole, M.J.A. De Bie, Org. Magn. Res. 8 (1976) 213-218, for a similar lack of Cu-C coupling in a copper(I) isocyanide complex.

[36] (a) G.L. Guillet, J.B. Gordon, G.N. Di Francesco, M.W. Calkins, E. Čižmár, K.A. Abboud, M.W. Meisel, R. García-Serres, L.J. Murray, Inorg. Chem. 54 (2015) 26912704. (b) B. Cristovao, B. Miroslaw, J. Klak, M. Rams, Polyhedron 85 (2015) 697-704. (c) S.S. Massoud, F.R. Louka, M.A. Al-Hasan, R. Vicente, F.A. Mautner, New J. Chem. 39 (2015) 5944-5952. (d) A.K. Ghosh, M. Pait, M. Shatruk, V. Bertolasi, D. Ray, Dalton Trans. 43 (2014) 1970-1973. (e) U.R. Pokharel, F.R. Fronczek, A.W. Maverick Nat. Commun. 5 (2014) 5883. (f) H. Takisawa, Y. Morishima, S. Soma, R.K. Szilagyi, K. Fujisawa, Inorg. Chem. 53 (2014) 8191-8193. (g) B. Zhang, X. Zheng, H. Su, Y. Zhu, C. Du, M. Song, Dalton Trans. 42 (2013) 8571-8574. (h) S.K. Dey, R. Chutia, G. Das, Inorg. Chem. 51 (2012) 1727-1738.

[37] (a) E.C.M. Ording-Wenker, M.A. Siegler, E. Bouwman, Inorg. Chim. Acta 428 (2015) 193-202. (b) E.C.M. Ording-Wenker, M. Van der Plas, M.A. Siegler, C. Fonseca Guerra, E. Bouwman, Chem. Eur. J. 20 (2014) 16913-16921. (c) E.C.M. Ording-Wenker, M. Van der Plas, M.A. Siegler, S. Bonnet, F.M. Bickelhaupt, C. Fonseca Guerra, E. Bouwman, Inorg. Chem. 53 (2014) 8494-8504. (d) A.M. Thomas, B.-L. Lin, E.C. Wasinger, T.D.P. Stack, J. Am. Chem. Soc. 135 (2013) 18912-18919. (e) A. Neuba, R. Haase, W. Meyer-Klaucke, U. Flörke, G. Henkel, Angew. Chem., Int. Ed. 51 (2012) 1714-1718. (f) W. Rammal, C. Belle, C. Béguin, C. Duboc, C. Philouze, J.-L. Pierre, L. Le Pape, S. Bertaina, E. Saint-Aman, S. Torelli, Inorg. Chem. 45 (2006) 10355-10362. (g) T. Osako, Y. Ueno, Y. Tachi, S. Itoh, Inorg. Chem. 43 (2004) 6516-6518. (h) Y. 
Ueno, Y. Tachi, S. Itoh, J. Am. Chem. Soc. 124 (2002) 12428-12429. (i) S. Itoh, M. Nagagawa, S. Fukuzumi, J. Am. Chem. Soc. 123 (2001) 4087-4088. (j) R.P. Houser, J.A. Halfen, V.G. Young, Jr., N.J. Blackburn, W.B. Tolman, J. Am. Chem. Soc. 117 (1995) 10745-10746. 